Universidade de São Paulo

Escola Superior de Agricultura "Luiz de Queiroz"

Avaliação de procedimento de ensaio para determinação da sensibilidade de gotejadores à obstrução por partículas sólidas

\title{
Rogerio Lavanholi
}

Dissertação apresentada para obtenção do título de Mestre em Ciências. Área de concentração: Engenharia de Sistemas Agrícolas

Piracicaba 


\section{Rogerio Lavanholi \\ Engenheiro Agrícola}

\section{Avaliação de procedimento de ensaio para determinação da sensibilidade de gotejadores à obstrução por partículas sólidas \\ versão revisada de acordo com a resolução CoPGr 6018 de 2011}

Orientador:

Prof. Dr. JOSE ANTONIO FRIZZONE

Dissertação apresentada para obtenção do título de Mestre em Ciências. Área de concentração: Engenharia de Sistemas Agrícolas

\section{Piracicaba}




\title{
Dados Internacionais de Catalogação na Publicação DIVISÃO DE BIBLIOTECA - DIBD/ESALQ/USP
}

\begin{abstract}
Lavanholi, Rogerio
Avaliação de procedimento de ensaio para determinação da sensibilidade de gotejadores à obstrução por partículas sólidas / Rogerio Lavanholi. - - versão revisada de acordo com a resolução CoPGr 6018 de 2011. - - Piracicaba, 2016.

65 p. : il.

Dissertação (Mestrado) - - Escola Superior de Agricultura "Luiz de Queiroz".
\end{abstract}

1. Microirrigação 2. Qualidade da água 3. Partículas suspensas 4. Solo natural I. Título

CDD 631.7

L395a

"Permitida a cópia total ou parcial deste documento, desde que citada a fonte - O autor" 
Aos meus pais Antônio Lavanholi e Clenir Belone Lavanholi A minha irmã Cristina Lavanholi Ao meu irmão Douglas Antônio Lavanholi 


\section{AGRADECIMENTOS}

Agradeço a Deus, pela vida, pela fé e pela força nos momentos de dificuldade.

A minha família por todo incentivo que me foi dado ao longo dessa caminhada.

A Escola Superior de Agricultura "Luiz de Queiroz" (ESALQ/USP) e ao Programa de PósGraduação em Engenharia de Sistemas Agrícolas pela oportunidade, estrutura e suporte técnico oferecidas para realização do curso e da pesquisa.

Ao Ministério da Ciência e Tecnologia (MCT), a Coordenação de Aperfeiçoamento de Pessoal de Nível Superior (CAPES), ao Conselho Nacional de Desenvolvimento Científico e Tecnológico (CNPq) e à Fundação de Amparo à Pesquisa do Estado de São Paulo (FAPESP), pelo apoio financeiro a esta pesquisa, através do Instituto Nacional de Ciência e Tecnologia em Engenharia da Irrigação (INCTEI).

A Coordenação de Aperfeiçoamento Pessoal de Nível Superior (CAPES), pelo apoio financeiro por meio de bolsa de estudos.

Ao professor José Antônio Frizzone pela orientação e pela confiança depositada em mim.

Aos técnicos do LEB, especialmente ao Antonio Pires de Camargo, pelo acompanhamento, apoio, sugestões e auxílio na realização desta pesquisa.

Ao Fabrício Correia de Oliveira e Hermes Soares da Rocha pelo auxílio na montagem e condução do experimento, e revisão deste e demais textos.

A equipe do laboratório francês, LERMI/IRSTEA, pelo apoio prestado no decorrer desta pesquisa.

Aos funcionários e professores do Departamento de Engenharia de Biossistemas (LEB) pelo auxílio e disponibilidade.

Ao Prof. Dr. Rubens Duarte Coelho por disponibilizar a bancada para ensaios de obstrução de gotejadores.

Aos amigos e colegas de Pós-Graduação e república pelos bons momentos vividos e pelo apoio durante minha permanência em Piracicaba. 
Por fim, agradeço a todos que de alguma forma contribuíram com essa pesquisa e também com minha formação, tanto acadêmica como pessoal. 


\section{SUMÁRIO}



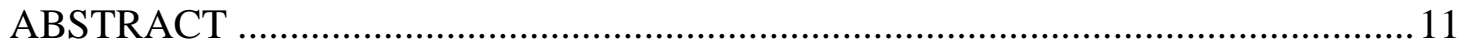

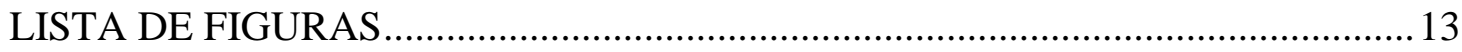

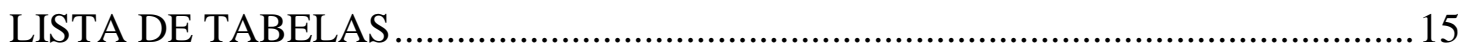



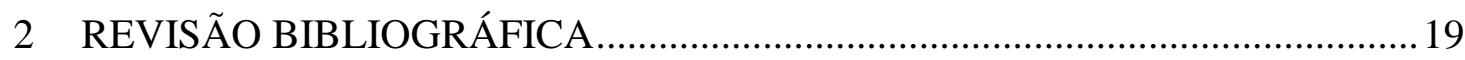

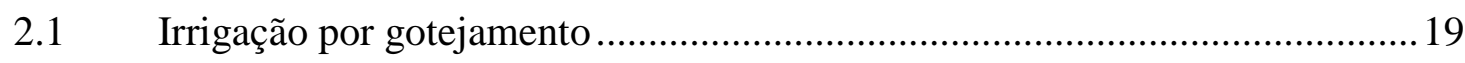

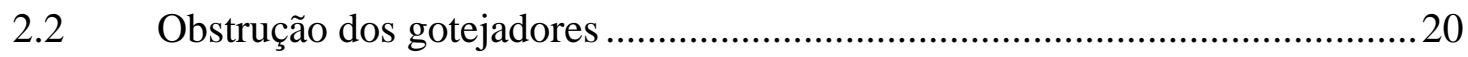



2.4 Procedimentos de ensaios de obstrução de gotejadores...................................2 24



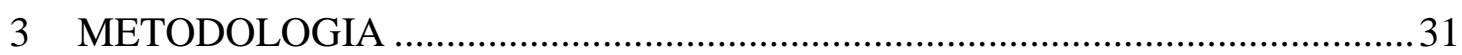





3.3 Escolha dos bocais para controle da vazão nas linhas laterais......................... 33

3.4 Dimensionamento do sistema de distribuição de água e recalque................... 34

3.5 Uniformidade de distribuição de água do sistema ..........................................36

3.6 Partículas sólidas utilizadas para os ensaios de obstrução................................37



3.8 Avaliação da sensibilidade de gotejadores à obstrução ................................. 44

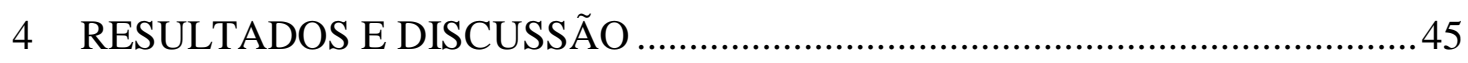

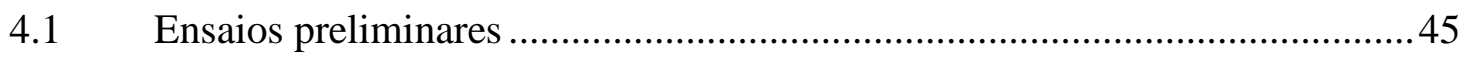

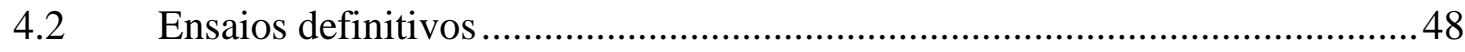

4.3 Avaliação da obstrução dos emissores em função das dimensões...................56

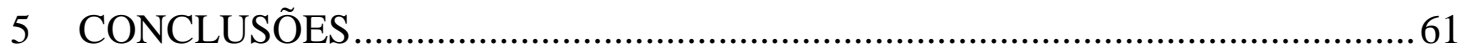

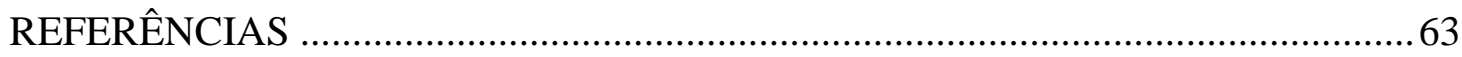




\section{RESUMO}

\section{Avaliação de procedimento de ensaio para determinação da sensibilidade de gotejadores à obstrução por partículas sólidas}

A obstrução de emissores tem sido considerada como um dos principais problemas do sistema de irrigação por gotejamento, sendo a obstrução de origem física a forma mais comum de ocorrência. A obstrução pode causar aos sistemas de irrigação por gotejamento redução da uniformidade de distribuição de água e da vida útil do sistema, tornando-se necessário uma metodologia para avaliar os efeitos causados pela obstrução sobre os sistemas de irrigação. Salienta-se que não há atualmente uma norma técnica em vigor que estabeleça os requisitos para avaliar a sensibilidade de emissores à obstrução causada por partículas sólidas. Contudo, um procedimento de ensaio elaborado pela equipe do laboratório francês Laboratoire d'Études et Recherches sur les Matériels d'Irrigation/Institut national de recherche en sciences et technologies pour l'environnement et l'agriculture (LERMI/IRSTEA) tem sido utilizado para a avaliação de produtos comerciais há aproximadamente 40 anos. Considerado apropriado pelo laboratório e por empresas, esse procedimento tem sido indicado para elaboração de uma norma técnica subsequente à realização de estudos para avaliação metodológica. Dessa forma, o objetivo deste trabalho foi realizar um estudo para avaliar o protocolo de ensaios utilizado pelo LERMI/IRSTEA, a fim de contribuir com a validação da metodologia e colaborar com resultados científicos que amparem um procedimento normatizado de ensaio. Para avaliar a metodologia foram realizados três ensaios, considerados como repetições, utilizando quatro modelos de tubos gotejadores (Drip-Tech 1,2 e 1,6 L h$~^{-1}$ e Taldrip 0,6 e 1,7 $\mathrm{L} \mathrm{h}^{-1}$ ). Na realização dos experimentos foi utilizado material de obstrução originado de solo natural, preparado por meio de destruição da matéria orgânica, dispersão da argila e peneiramento do solo. O ensaio foi divido em quatro fases, com diferentes concentrações e faixas granulométricas do material de obstrução. As concentrações utilizadas em cada fase foram: 125, 250, 375 e $500 \mathrm{mg} \mathrm{L}^{-1}$. As faixas granulométricas adicionadas foram: < 75, 75-125, 125-212, 212-500 $\mu \mathrm{m}$ para as fases um, dois, três e quatro, respectivamente, sendo que o material de obstrução permaneceu em reservatório com agitação constante a fim de manter as partículas em suspensão. Os resultados demonstraram que os modelos de gotejadores Drip-Tech 1,2 e 1,6 L h ${ }^{-1}$ obstruíram na quarta fase de ensaio. O modelo Taldrip $0,6 \mathrm{~L} \mathrm{~h}^{-1}$ mostrou-se muito sensível à obstrução logo na primeira fase de ensaio apresentando obstrução de emissores no primeiro dia. $\mathrm{O}$ modelo Taldrip $1,7 \mathrm{~L} \mathrm{~h}^{-1}$ não obstruiu em nenhuma das fases sendo considerado um emissor resistente à obstrução para as condições experimentais avaliadas. Embora a obstrução dos modelos de gotejadores avaliados tenha ocorrido sempre em uma determinada fase, a variabilidade dos resultados de grau de obstrução entre repetições foi elevada. A principal hipótese que justifica esse resultado é que fatores não controlados exerceram influência significativa nos processos de obstrução durante os experimentos. Considera-se que o procedimento de ensaio deve ser aprimorado por meio da identificação e controle de outros fatores relevantes para o processo de obstrução (como $\mathrm{pH}$, concentração de partículas, cloração da água), a fim de que os resultados sejam mais precisos e o procedimento de ensaios torne-se mais representativo.

Palavras-chave: Microirrigação; Qualidade da água; Partículas suspensas; Solo natural 


\section{ABSTRACT \\ Evaluation of a testing procedure to assess the sensitivity of emitters to clogging due to solid particles}

Clogging of emitters has been considered a major problem in drip irrigation systems and solid particles are reported as the most common source of such problems. Clogging of emitters may decrease water distribution uniformity and system lifespan, which become needed a methodology to assess the effects of clogging of drippers on irrigations systems. There is not standard available that states requirements to assess the sensitivity of emitters to clogging caused by solid particles. However, a clogging test procedure developed by the French laboratory Laboratoire d'Études et Recherches sur les Matériels d'Irrigation/Institut national de recherche en sciences et technologies pour l'environnement et l'agriculture LERMI/IRSTEA about 40 years ago has been employed to evaluate drippers. According to the laboratory and their customers, that is an appropriate testing procedure which represents field conditions, and has been indicate like standard, after studies to assess of methodology. The purpose of this research was to evaluate the clogging test procedure used by LERMI/IRSTEA in order to contribute for the methodology validation and to present scientific results that support development of a standardized clogging test protocol. Experiments were organized in three repetitions, in which four models of drippers were tested (Drip-Tech 1.2 e $1.6 \mathrm{~L} \mathrm{~h}^{-1}$ e Taldrip 0.6 e $1.7 \mathrm{~L} \mathrm{~h}^{-1}$ ). The solid particles compound employed during clogging tests was prepared from samples of natural soil that were submitted to a preparation procedure consisting of destruction of organic matter, clay dispersion, and sieving. The clogging test procedure is divided into four stages. The following concentrations of particles were tested: $125,250,375$ and $500 \mathrm{mg} \mathrm{L}^{-1}$. The ranges of particle sizes tested were: $<75,75-125,125-212$, and $212-500 \mu \mathrm{m}$ to the stages one, two, three and four, respecting, wherein the particles remained in the tank with constant agitation to keep the particles in suspension. Drippers model Drip-tech $1.2 \mathrm{~L} \mathrm{~h}^{-1}$ and $1.6 \mathrm{~L} \mathrm{~h}^{-1}$ were considered to clog during the fourth stage of the tests. The dripper Taldrip $0.6 \mathrm{~L} \mathrm{~h}^{-1}$ was sensitive to clogging in the first stage with clogging emitters in the first day. The dripper Taldrip $1.7 \mathrm{~L} \mathrm{~h}^{-1}$ did not clog during the tests so that it seems to be a model of low sensitivity to clogging caused by solid particles in the experimental conditions assessed. In respect of the testing procedure, although clogging of drippers had been identified always in a given stage of the test, most of times the variability in clogging rate among repetitions was excessive. Probably non-controlled factors exerted significant influence on clogging processes during experiments. The clogging test procedure needs improvements by identifying and controlling other relevant factors associated with clogging processes (as $\mathrm{pH}$, concentration of particles, chlorination water) in order the results are more accurate and the test procedures become more representative.

Keywords: Microirrigation; Water quality; Suspension particles; Natural soil 


\section{LISTA DE FIGURAS}

Figura 1 - Esquema das características geométricas dos emissores Taldrip 0,6 $\mathrm{L} \mathrm{h}^{-1}$ (a); Taldrip 1,7 $\mathrm{L} \mathrm{h}^{-1}$ (b); Drip-Tech 1,6 L h${ }^{-1}$; e Drip-Tech 1,2 $\mathrm{L} \mathrm{h}^{-1}$ (c). Dimensões dos labirintos dos emissores Taldrip $0,6 \mathrm{~L} \mathrm{~h}^{-1}(\mathrm{~d})$; Taldrip $1,7 \mathrm{~L} \mathrm{~h}^{-1}$ (e); DripTech 1,2 L h ${ }^{-1}$; e Drip-Tech $1,6 \mathrm{~L} \mathrm{~h}^{-1}(\mathrm{f})$. 31

Figura 2 - Esquema da bancada para ensaios de obstrução 32

Figura 3 - Linha de derivação com bifurcações simétricas. 33

Figura 4 - Vazão dos bocais de pivô central selecionados para o controle da vazão nas laterais 34

Figura 5 - Esquema dos trechos dimensionados do sistema de distribuição de água ............... 36

Figura 6 - Vazão das oito linhas laterais utilizando tubos de polietileno liso.......................... 36

Figura 7 - Curva granulométrica do solo utilizado para obtenção do material de obstrução .. 37

Figura 8 - Béqueres sobre placa aquecedora (a); recipientes contendo solo com agente dispersante no agitador horizontal tipo shaker (b); Peneira de $44 \mu \mathrm{m}$ após a lavagem das partículas (c); e agitador com peneiras para separação das partículas em diferentes faixas granulométricas (d)

Figura 9 - Curva de distribuição granulométrica do material de obstrução utilizado para os ensaios experimentais

Figura 10 - Bancada de ensaio e coletores utilizados para monitoramento da vazão. 43

Figura 11 - Grau de obstrução e número de emissores obstruídos ao longo dos ensaios nas quatro fases: (a) Drip-Tech 1,2 $\mathrm{L} \mathrm{h}^{-1}$; (b) Drip-Tech $1,6 \mathrm{~L} \mathrm{~h}^{-1}$; (c) Taldrip $0,6 \mathrm{~L} \mathrm{~h}^{-}$ ; e, (d) Taldrip 1,7 $\mathrm{L} \mathrm{h}^{-1}$

Figura 12 - Material no interior do gotejador (a); imagem microscópica do material encontrado no gotejador (b e c); imagem do microscópio do pano utilizado para secagem dos coletores (d); imagem do microscópio do barbante (e); e imagem do microscópio da veda rosca (f) 48

Figura $13-\mathrm{pH}$ (a) e temperatura da água (b) para cada repetição em cada dia de ensaio....... 49

Figura 14 - Grau de obstrução e número de emissores obstruídos nas três repetições para os quatro modelos estudados

Figura 15 - Diferenças entre grau de obstrução máximo e mínimo entre repetições para os quatro modelos de emissores estudados.

Figura 16 - Detalhe do emissor Drip-Tech 1,2 $\mathrm{L} \mathrm{h}^{-1}$ que apresentou uma "rebarba" devido a falhas no processo de fabricação. 
Figura 18 - Obstrução ocorrida no meio do labirinto para o emissor Taldrip $0,6 \mathrm{~L} \mathrm{~h}^{-1}$ (a); obstrução na entrada do labirinto no modelo Taldrip $0,6 \mathrm{~L} \mathrm{~h}^{-1}$ (b); Drip-Tech 1,6

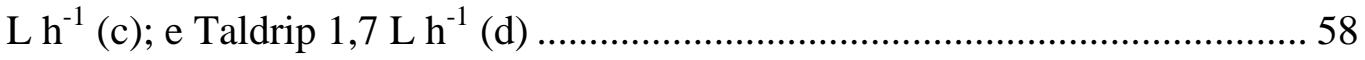

Figura 19 - Obstrução ocorrida pelo acúmulo de partículas de areia (a) e obstrução ocorrida pela formação de agregados de argila (b) 59 


\section{LISTA DE TABELAS}

Tabela 1 - Classificação da qualidade da água, relativa ao potencial de obstrução de gotejadores 22

Tabela 2 - Concentrações e propriedades do material de obstrução em cada fase do protocolo de ensaio de resistência à obstrução de gotejadores 26

Tabela 3 - Cronograma com tempo de ensaio, concentração de partículas e faixa granulométrica de partículas sólidas do ensaio de resistência à obstrução de

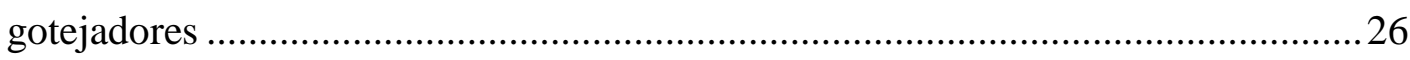

Tabela 4 - Características técnicas dos emissores selecionados 32

Tabela 5 - Diâmetro de cada trecho (recalque e sistema de distribuição) com suas respectivas velocidades críticas e velocidade de escoamento 36

Tabela 6 - Faixas granulométricas utilizadas pelo LERMI e faixas granulométricas utilizadas no experimento para cada etapa

Tabela 7 - Peneiras utilizadas para separação dos intervalos de diâmetro de partículas e contribuição de cada intervalo na composição da faixa granulométrica do material nos ensaios de obstrução 41

Tabela 8 - Distribuição da concentração das faixas granulométricas em cada etapa 42 


\section{INTRODUÇÃO}

Não há atualmente norma técnica em vigor que descreva os requisitos para avaliação da sensibilidade de emissores à obstrução. Os mecanismos de obstrução são complexos e ainda não existe um entendimento consolidado sobre os fenômenos atuantes. Um procedimento adequado para ensaios em laboratório deve incluir os fatores predominantes no processo de obstrução e, principalmente, reproduzir situações de campo nas quais o material realmente opera. Também é essencial que o procedimento juntamente com as estruturas de ensaios propiciem índices de repetitividade e reprodutibilidade com baixa incerteza, a fim de que um dado modelo de material sempre apresente resultados similares de desempenho, mesmo quando avaliado por laboratórios distintos.

Do ponto de vista de laboratórios de ensaio, um procedimento de ensaio viável tecnicamente e economicamente precisa apresentar curta duração, mas suficiente para assegurar adequada avaliação de desempenho do material. O grande desafio, e que motiva divergências em discussões sobre ensaios de obstrução, refere-se à definição de quais fatores devem ser incluídos em um procedimento laboratorial de ensaios e, para cada fator incluído, quantos níveis de ensaio são necessários. Fatores e níveis de ensaio não podem simplesmente ser arbitrados, e precisam de fundamentação teórica obtida por meio de pesquisa, para que se possa estabelecer um procedimento adequado. O compromisso de um laboratório que presta serviços de avaliação de desempenho de material de irrigação para fabricantes é sempre alto, assim os resultados de ensaios precisam apresentar qualidade e confiabilidade.

Pesquisas têm demonstrado que diferentes emissores submetidos às mesmas condições de operação apresentam respostas distintas em relação a susceptibilidade à obstrução. Diante dos inúmeros modelos de emissores disponíveis no mercado, torna-se necessário uma metodologia que permita identificar o risco de obstrução que determinado emissor apresenta, para assim contribuir para dimensionamento do sistema de filtragem e/ou metodologias de tratamento que a água deve ser submetida.

O documento N919 corresponde a uma proposta de norma para avaliação da sensibilidade de emissores à obstrução, que está em fase de elaboração pelo comitê ISO/TC 23/SC 18 -"Irrigation and drainage equipment and systems", sendo que o pesquisador Bruno Molle, gerente do LERMI/IRSTEA e colaborador dessa pesquisa, lidera esse projeto de norma junto ao referido comitê. Devido à complexidade dos mecanismos de obstrução e

divergências de opiniões no comitê da ISO, evidenciou-se a necessidade da busca por fundamentos teóricos para dar suporte à definição de requisitos e procedimentos de ensaio da 
futura norma técnica. Acerca disso, atividades de pesquisa relacionada a mecanismos de obstrução vem sendo desenvolvidas entre o Laboratório de Ensaios de Material de Irrigação do Instituto Nacional de Ciência e Tecnologia em Engenharia da Irrigação na Escola Superior de Agricultura "Luiz de Queiroz" (LEMI/INCT-EI/ESALQ/USP) e o LERMI/IRSTEA. O presente trabalho faz parte das pesquisas que vêm sendo realizadas em parceria e visa dar suporte técnico-científico a norma ISO em elaboração.

A metodologia adotada no projeto da norma é baseada na metodologia utilizada pelo laboratório francês LERMI/IRSTEA, que tem utilizado o procedimento de ensaios de obstrução há aproximadamente 40 anos, considerado por empresas e especialistas um método confiável. O procedimento de ensaio visa a avaliação da sensibilidade de emissores à obstrução causada por partículas sólidas, sendo sua metodologia descrita no decorrer desse documento.

Estudos desenvolvidos sobre sensibilidade de emissores à obstrução têm utilizado diferentes metodologias de ensaio. Metodologias e/ou estruturas de ensaios inadequadas podem conduzir a resultados pouco confiáveis, que não podem ser reproduzidos em condições de ensaio similares, ou ainda, que não reproduzem condições reais observadas a campo. Apesar do LERMI/IRSTEA ser um laboratório renomado, é necessária a apresentação de evidências científicas para confirmação de que a metodologia utilizada é adequada. Desta forma, a hipótese do trabalho é: o método apresentado pelo documento N919 é adequado para avaliar a sensibilidade de emissores à obstrução por partículas sólidas.

O objetivo desta pesquisa foi avaliar o protocolo de ensaios utilizado pelo LERMI/IRSTEA, a fim de contribuir com a validação da metodologia e colaborar com resultados científicos que dê suporte a um procedimento normatizado de ensaio. 


\section{REVISÃO BIBLIOGRÁFICA}

\subsection{Irrigação por gotejamento}

O sistema de irrigação por gotejamento está inserido no método localizado de aplicação de água, também denominado microirrigação. Nesse sistema o fornecimento de água para as plantas ocorre diretamente na região do sistema radicular. A água é aplicada em baixa intensidade e alta frequência, e quando bem manejada, mantém a umidade do solo próximo às condições ideais de cultivo (BERNARDO; SOARES; MONTOVANI, 2006).

A irrigação por gotejamento apresenta como principais vantagens, baixo consumo energético, elevada uniformidade de distribuição de água, possibilidade de aplicações de fertilizantes via água de irrigação (BORSSOI et al., 2012; LI et al., 2012; WU, 1997), e baixa perda por evaporação (BERNARDO; SOARES; MONTOVANI, 2006). No entanto, a expansão de áreas irrigadas por esse sistema ainda é limitada devido ao elevado custo de aquisição e maior demanda de conhecimento técnico para operação, principalmente devido a maior necessidade de um monitoramento da qualidade da água de irrigação, de modo que em caso de negligência, pode-se ocorrer a redução da vida útil do sistema devido principalmente a obstrução dos emissores (BOUNOUA, 2010; NAKAYAMA; BUCKS, 1991).

A uniformidade de distribuição de água é um importante parâmetro a ser monitorado no sistema de irrigação por gotejamento, uma vez que variações de vazão ao longo das linhas laterais podem interferir no fornecimento de água às plantas assim como de nutrientes durante o processo de fertirrigação. A origem dessas variações está associada à temperatura da água, pressão de operação, fabricação do emissor, variações topográficas, perda de carga e obstrução de emissores (VEKARIYA et al., 2011). No entanto, a obstrução de emissores é reportada como uma das maiores responsáveis pela redução da uniformidade de distribuição de água, assim como o comprometimento da vida útil dos equipamentos (BUCKS; NAKAYAMA; GILBERT, 1979; CAMARGO et al., 2013).

Em sistemas de irrigação por gotejamento o controle da vazão é realizado pelos gotejadores, considerados como os principais componentes desse sistema. Esses emissores conduzem a água por labirintos de reduzidas dimensões, e são responsáveis por dissipar a pressão disponível na linha lateral e controlar a vazão do gotejador, permitindo que a água seja aplicada ao solo com baixa vazão e uniforme. Contudo, o bom desempenho dos gotejadores pode ser comprometido pela qualidade da água utilizada no sistema (NAKAYAMA; BUCKS, 1991), fator limitante para irrigação localizada devido às pequenas 
dimensões dos caminhos de passagem de água no interior dos emissores (RAVINA et al., 1992).

\subsection{Obstrução dos gotejadores}

A obstrução de gotejadores tem sido apontada como um dos principais problemas do sistema de irrigação por gotejamento (BUCKS; NAKAYAMA; GILBERT, 1979), podendo ser associada à qualidade da água de irrigação utilizada (NAKAYAMA; BUCKS, 1991). São diversas as causas que podem provocar obstrução parcial ou completa dos emissores e, e com isso, a redução da uniformidade de distribuição (NAKAYAMA; BUCKS, 1991). Contudo, as principais causas operacionais que levam os emissores à obstrução são: sistema de filtragem ineficiente, tratamento inadequada da água, e baixa frequência de limpeza das tubulações laterais (LAMM; CAMP, 2007).

O problema de obstrução tem como origem a ação individual ou combinada de agentes de natureza química, biológica ou física (BUCKS; NAKAYAMA; GILBERT, 1979; PIZARRO, 1996), características também consideradas como indicativos da qualidade da água (GIRÃO et al., 2007). Essas características auxiliam na escolha do método de tratamento da água e no dimensionamento do sistema de filtragem, assim como a escolha do método de irrigação mais adequado (LI et al., 2012; NAKAYAMA; BUCKS, 1991).

A ação de agentes de natureza biológica é causada pelo desenvolvimento de microrganismos como algas, fungos e bactérias no interior do sistema de irrigação. Na maioria das vezes, esses microrganismos não são retidos pelo sistema de filtragem, desenvolvendo-se e formando colônias. Algumas bactérias, devido à oxidação do ferro dissolvido e do sulfeto de hidrogênio, originam biofilmes, agindo como adesivos que facilitam o acúmulo de argila, algas e outras partículas relativamente pequenas, proporcionando a obstrução gradual dos emissores (ADIN; SACKS, 1991). Como forma de evitar esse tipo de problema, a cloração da água é o principal método adotado para o controle da população de microrganismos (NAKAYAMA; BUCKS, 1991).

A obstrução de natureza química, na maioria das vezes, é resultado da precipitação de íons, formando incrustações que podem bloquear a passagem de água no interior do emissor. São diversos os fatores que condicionam a precipitação de íons, sendo o pH da água apontado como o fator de maior relevância (LAMM; CAMP, 2007). Mantendo-se o pH da água de irrigação inferior a sete, grande parte dos problemas ligados à precipitação de íons são evitados, assim como a proliferação de microrganismos (PINTO et al., 2011). 
Problemas de obstrução por natureza física são ocasionados pela presença de partículas em suspensão na água de irrigação, podendo ser de origem inorgânica ou orgânica (BUCKS, NAKAYAMA; GILBERT, 1979). Durante o funcionamento do sistema, esses materiais conseguem passar pelo orifício de entrada dos gotejadores e obstruem os percursos do escoamento da água nos emissores.

A ação dos agentes causadores da obstrução citados acima é agravada pelas dimensões e o arranjo arquitetônico com que os labirintos são projetados, considerados esses como parte das características geométricas dos emissores. Quando são submetidos a condições de operação com água de baixa qualidade, as características geométricas do percurso de passagem de fluxo nos emissores são relatadas como um dos fatores de maior relevância no grau de obstrução (TAYLOR et al., 1995). Para obter baixa vazão e alta uniformidade de irrigação, a maioria dos emissores comerciais atuais adotam canais de labirinto com uma secção de fluxo pequena (geralmente inferior à $1 \mathrm{~mm}^{2}$ ) (QINGSONG et al., 2008). Essas características aumentam a vulnerabilidade dos emissores, pois quanto menor a área de passagem de água, maior suscetibilidade à obstrução (RAVINA et al., 1992).

Em função das pequenas dimensões e pela complexidade que os emissores são confeccionados, torna-se difícil realizar a associação da sensibilidade à obstrução com as características geométricas dos emissores utilizando métodos convencionais de ensaio. No entanto, com o objetivo de estudar e avaliar o comportamento da obstrução em sistemas de irrigação por gotejamento, alguns pesquisadores utilizaram parâmetros como vazão total do sistema e pressão no recalque, nas linhas de distribuição e ao longo das linhas laterais, para estabelecer modelos estatísticos ou hidráulicos capazes de simular, analisar e detectar a ocorrência de obstrução dos emissores (BRALTS; WU; GITLIN, 1981; CAMARGO et al., 2013; NAKAYAMA; BUCKS, 1981; POVOA; HILLS, 1994; TALOZI; HILLS, 2001). Esses modelos estatísticos identificam e quantificam a ocorrência de obstruções nas linhas laterais em estágios iniciais, possibilitando a tomada de decisões que permitem controlar o progresso da obstrução no sistema, contudo não permitem relacionar a obstrução com as características geométricas dos emissores.

Podem ser encontradas cinco situações típicas de obstrução em sistemas de irrigação localizada: (1) obstrução é parcial e afeta igualmente todos os emissores; (2) obstrução é parcial e afeta parte dos emissores; (3) obstrução é completa e afeta igualmente parte dos emissores; (4) obstrução é completa e afeta igualmente todos os emissores; e (5) combinação de obstruções parciais e completas ao longo de toda lateral (BRALTS; WU; GITLIN, 1981). 
Diante do problema que a obstrução de emissores em irrigação localizada apresenta, é essencial a realização de estudos que busquem entender o fenômeno de obstrução quando emissores são submetidos a condições de operações adversas. No entanto, relacionar o risco de obstrução com as características da água de irrigação envolve a determinação dos componentes e as possíveis interações entre os mesmos. Isso tem dificultado a realização de pesquisas que objetivam solucionar o problema de obstrução dos emissores (BERNARDO; SOARES; MONTOVANI, 2006; BOUNOUA, 2010), sendo que na literatura especializada ainda não existe um consenso em relação ao método de avaliação do risco de obstrução, o que provavelmente se deve ao difícil entendimento do papel de cada fator no processo de obstrução (PIZARRO, 1996). Todavia, na tentativa de realizar uma orientação quantitativa, Bucks e Nakayama (1991) propuseram uma classificação da qualidade da água que possibilita determinar o risco de obstrução dos emissores (Tabela 1).

Tabela 1 - Classificação da qualidade da água, relativa ao potencial de obstrução de gotejadores

\begin{tabular}{lccc}
\hline Fatores de obstrução & \multicolumn{3}{c}{ Classificação de risco } \\
\cline { 2 - 4 } & Pequena & Moderada & Severa \\
\hline Físico & $<50$ & $50-100$ & $>100$ \\
$\quad$ Sólidos Suspensos $\left(\mathrm{mg} \mathrm{L}^{-1}\right)$ & & & $>8$ \\
Químicos & $<7$ & $7-8$ & $>2000$ \\
pH & $<500$ & $500-2000$ & $>1,5$ \\
Sólidos dissolvidos $\left(\mathrm{mg} \mathrm{L}^{-1}\right)$ & $<0,1$ & $0,1-0,5$ & $>1,5$ \\
Manganês $\left(\mathrm{mg} \mathrm{L}^{-1}\right)$ & $<0,2$ & $0,2-1,5$ & $>2,0$ \\
Ferro total $\left(\mathrm{mg} \mathrm{L}^{-1}\right)$ & $<0,2$ & $0,2-2$ & $>50000$ \\
Sulfeto de Hidrogênio $\left(\mathrm{mg} \mathrm{L}^{-1}\right)$ & & &
\end{tabular}

\subsection{Obstrução de natureza física}

A obstrução por partículas sólidas em suspensão tem sido apontada como a mais comum entre os tipos de obstrução (LI et al., 2012). Esse tipo de problema normalmente é ocasionado pela presença de partículas em suspensão que podem ser de origem inorgânica (areia, silte, argila e plásticos) e orgânica (organismos aquáticos, zooplâncton, caramujos, peixes, larvas de insetos, formigas e aranhas) (BUCKS; NAKAYAMA; GILBERT, 1979).

Sólidos suspensos que apresentam capacidade de obstrução dos percursos de fluxo de água nos emissores, na maioria das vezes, entram no sistema por meio da sucção de água com partículas em suspensão, durante a montagem do sistema de irrigação, ou também pela entrada de solo por meio dos gotejadores, devido a pressão negativa criada após o sistema de irrigação ser desligado (TAYLOR et al., 1995). 
Os principais fatores que influencia a obstrução por partículas em suspensão são: diâmetro e concentração das partículas. É difícil assegurar qual dos dois fatores apresenta a maior contribuição para com a obstrução dos emissores. Apesar de Adin e Sacks (1991) afirmarem que a severidade da obstrução, em muitos casos, depende mais do tamanho do que da quantidade de partículas na água de irrigação, é possível que o aumento da concentração de partículas na água de irrigação, mesmo que de pequenos diâmetros, ocasione efeito significativo na obstrução dos emissores (NIU; LIU; CHEN, 2013). Geralmente, partículas de origem inorgânica fazem parte da constituição do solo e podem ser separadas de acordo com o diâmetro médio das partículas como: areia (2 a 0,05 mm), silte $(0,05$ a 0,002 mm) e argila (menor que 0,002 mm) (BOUNOUA, 2010; HILLEL, 2003). O risco de obstrução por fatores físicos pode ser classificado de acordo com a concentração de partículas sólidas em suspensão. Teores menores que $50 \mathrm{mg} \mathrm{L}^{-1}$ possuem baixo risco de obstrução, enquanto que teores entre 50 e $100 \mathrm{mg} \mathrm{L}^{-1}$ apresentam grau moderado de risco, e teores acima de $100 \mathrm{mg} \mathrm{L}^{-}$ ${ }^{1}$ são classificados como alto risco de obstrução (BUCKS; NAKAYAMA; GILBERT, 1979).

A obstrução de natureza física pode ocorrer de duas formas, a saber: 1) obstrução por partículas de grande diâmetro, a qual ocorre quando o tamanho é maior que a seção de passagem do emissor (esse mecanismo é comum para partículas de areia); 2) obstrução por acúmulo lento de partículas, o qual é causado pela deposição gradual de partículas finas na tubulação, ocorrendo geralmente no final da linha gotejadora, onde a velocidade de escoamento é menor, e próximo à entrada do labirinto do emissor (BOUNOUA, 2010; BUCKS; NAKAYAMA; GILBERT, 1979; NIU; LIU; CHEN, 2013).

A utilização de sistemas de filtragem é o método mais comum para evitar a entrada de material particulado no sistema de irrigação. No entanto, partículas muito pequenas como as de argila, organismos microscópicos, algas e algumas bactérias, não são retidas pelo sistema de filtragem e podem causar obstrução pela formação de partículas maiores devido ao acúmulo e/ou agregação das partículas (BOUNOUA, 2010; NIU; LIU; CHEN, 2013). Outra estratégia adotada como prevenção da obstrução de emissores é a limpeza das laterais (flushing). Esse procedimento consiste na abertura do fim de linhas possibilitando a remoção de partículas por meio do fluxo de água (PUIG-BARGUÉS et al., 2010), reduzindo o risco de obstrução. 


\subsection{Procedimentos de ensaios de obstrução de gotejadores}

Atualmente não existe um protocolo de ensaio padrão que regulamente a metodologia de ensaio de obstrução de gotejadores, possivelmente devido à complexidade do problema de obstrução, que pode ser afetado por fatores como qualidade da água e características geométricas dos gotejadores. Ainda não há um entendimento consolidado sobre os fenômenos que atuam na obstrução dos emissores, dificultando a elaboração de uma norma técnica que indique um método seguro para avaliar a suscetibilidade dos gotejadores à obstrução.

Pesquisas destinadas à avaliação do risco de obstrução de gotejadores submetidos a condições de operação com água de baixa qualidade têm sido desenvolvidas, entretanto as metodologias utilizadas apresentam procedimentos distintos. Niu, Liu e Chen (2013) realizaram ensaios de obstrução de gotejadores utilizando misturas com partículas de diâmetros inferiores a $0,10 \mathrm{~mm}$. O método de ensaio adotado pelos autores consistiu no monitoramento de 15 emissores divididos em quatro tubos gotejadores instalados em uma bancada de ensaio em laboratório. O monitoramento da vazão de cada emissor foi realizado por meio de um sistema automatizado utilizando coletores equipados com sensores de massa. Nesse ensaio, foi utilizada água com parâmetros dentro do padrão de qualidade de água de irrigação na China. O procedimento de ensaio foi dividido em oito etapas com diferentes faixas granulométricas: 1) $0,10-0,075 \mathrm{~mm}$; 2) 0,075-0,061 mm;3) 0,061-0,058 mm; 4) 0,058-0,045 mm; 5) 0,045-0,038 mm; 6) 0,038-0,034 mm; 7) 0,038-0,034 mm; e 8) <0,031 $\mathrm{mm}$

Cada etapa foi subdivida em oito fases com diferentes concentrações: 0,25;0,50;0,75; 1,$00 ; 1,25 ; 1,50 ; 1,75$ e $2,00 \mathrm{~g} \mathrm{~L}^{-1}$, trabalhando de forma intermitente. O procedimento em cada uma das etapas inicia com o sistema operando por 30 minutos com a concentração de $0,25 \mathrm{~g} \mathrm{~L}^{-1}$. Em seguida, o sistema é desligado por um período de 6 horas até o início da próxima fase. Na segunda fase, incrementa-se $0,25 \mathrm{~g} \mathrm{~L}^{-1}$ na mistura, então o sistema opera por mais 30 minutos com a concentração de $0,50 \mathrm{~g} \mathrm{~L}^{-1}$. Posteriormente, novamente o sistema é desligado por um intervalo de 6 horas até o início da próxima etapa. Esse procedimento foi executado para as oito etapas de cada faixa granulométrica. Os resultados demonstraram que, para partículas finas (diâmetro inferior a $0,1 \mathrm{~mm}$ ), a severidade da obstrução está principalmente relacionada com a concentração de partículas dispersas na água.

Os resultados obtidos indicam que a obstrução causadas por partículas finas ocorre em locais similares à obstrução causada por partículas grandes, ou seja, geralmente ocorre na entrada e nos cantos do canal de escoamento. Com relação aos principais fatores que afetaram 
o desempenho dos emissores, os autores destacam a concentração e o tamanho das partículas. Em curto tempo de irrigação e para partículas com diâmetro inferior a $0,1 \mathrm{~mm}$, os autores observaram que concentrações de partículas inferior a 1,25 g $\mathrm{L}^{-1}$ não afetam significativamente a obstrução dos emissores, enquanto que concentração superiores a esse valor a vazão dos emissores varia intensamente.

Wei et al. (2008) utilizaram um protocolo de ensaio em laboratório para rápida avaliação do desempenho antiobstrução de emissores gotejadores utilizando areia com granulometria inferior a $0,425 \mathrm{~mm}$. O método proposto foi dividido em 8 fases de testes, com duração de 50 minutos cada. As fases foram iniciadas com o sistema pressurizado por um período de 15 minutos com mensuração da vazão de 25 emissores nos dois últimos minutos. Em seguida, o ensaio foi interrompido por 30 minutos, e depois o sistema religado por mais 5 minutos, sem nenhuma medição de vazão, com o objetivo de simular o funcionamento intermitente dos gotejadores. Na primeira fase, os emissores foram operados com solução contendo $250 \mathrm{mg} \mathrm{L}^{-1}$ da menor faixa granulométrica. Ao fim de cada fase foram adicionadas ao tanque $250 \mathrm{mg} \mathrm{L}^{-1}$ de uma nova mistura de partículas com diferente granulometria de acordo com a Tabela 2. As propriedades especificas do material de entupimento foram estabelecidas de acordo com a norma ISO 8486-1 (1996).

Segundo os autores a sensibilidade à obstrução dos emissores pode ser obtida por meio do experimento de curta duração realizado em laboratório proposto pelo estudo desenvolvido, sendo que o procedimento foi capaz de identificar a faixa granulométrica que os emissores são sensíveis. Por outro lado, os autores afirmam que a forma e as propriedades químicas do material de obstrução utilizado não são os mesmos que os materiais encontrados em água de irrigação em campo, sugerindo-se a realização de um procedimento de validação dos resultados obtidos por meio da execução de um sistema de irrigação por gotejamento em campo utilizando os mesmos modelos de emissores utilizados no estudo. 
Tabela 2 - Concentrações e propriedades do material de obstrução em cada fase do protocolo de ensaio de resistência à obstrução de gotejadores

\begin{tabular}{cccccccccc}
\hline & \multicolumn{7}{c}{ Graduação do tamanho da areia } & \multicolumn{2}{c}{$\begin{array}{c}\text { Concentração } \\
\text { Fases do ensaio }\end{array}$} \\
\cline { 2 - 9 } & F220 & F180 & F150 & F120 & F100 & F80 & F70 & F60 & $\left(\right.$ L $\left.^{-1}\right)$ \\
\hline Fase 1 & 250 & - & - & - & - & - & - & - & 250 \\
Fase 2 & 250 & 250 & - & - & - & - & - & - & 500 \\
Fase 3 & 250 & 250 & 250 & - & - & - & - & - & 750 \\
Fase 4 & 250 & 250 & 250 & 250 & - & - & - & - & 1000 \\
Fase 5 & 250 & 250 & 250 & 250 & 250 & - & - & - & 1250 \\
Fase 6 & 250 & 250 & 250 & 250 & 250 & 250 & - & - & 1500 \\
Fase 7 & 250 & 250 & 250 & 250 & 250 & 250 & 250 & - & 1750 \\
Fase 8 & 250 & 250 & 250 & 250 & 250 & 250 & 250 & 250 & 2000 \\
\hline
\end{tabular}

Fonte: Wei et al. (2008).

Faria (2013) realizou um trabalho com a proposta de desenvolver um procedimento de ensaio de obstrução de gotejadores para elaboração de uma norma técnica. O estudo foi conduzido em uma bancada com 126 amostras de tubos gotejadores de 12 modelos diferentes. A vazão dos gotejadores de cada seguimento de tubo foi obtida pela média da vazão de 10 emissores monitorados em cada amostra. O procedimento de ensaio foi divido em sete fases de avaliação, com duração de 80 horas de funcionamento em cada fase, operando por 8 horas diárias. O trabalho foi desenvolvido utilizando três faixas granulométricas $(0,05-0,1 ; 0,1-0,25$ e $0,25-0,5 \mathrm{~mm}$ ) em duas concentrações $\left(125\right.$ e $\left.500 \mathrm{mg} \mathrm{L}^{-1}\right)$ utilizando como material de obstrução areia de filtro (material comercial). O cronograma de ensaio com as fases e suas respectivas concentrações e faixas granulométricas são apresentadas na Tabela 3.

Tabela 3 - Cronograma com tempo de ensaio, concentração de partículas e faixa granulométrica de partículas sólidas do ensaio de resistência à obstrução de gotejadores

\begin{tabular}{lcccccccc}
\hline Tempo & Hora & 0 & 80 & 160 & 240 & 320 & 400 & 480 \\
\hline Avaliações & $(\mathrm{N})$ & 1 & 2 & 3 & 4 & 5 & 6 & 7 \\
\hline Concentrações & $(\mathrm{ppm})$ & 0 & 125 & 125 & 125 & 500 & 500 & 500 \\
\hline Areia Média & $(\mathrm{mm})$ & - & - & - & $0,25-0,5$ & - & - & $0,25-0,5$ \\
Areia Muito Fina & $(\mathrm{mm})$ & - & - & $0,1-0,25$ & - & - & $0,1-0,25$ & - \\
Areia Muito Fina & $(\mathrm{mm})$ & - & $0,05-0,1$ & - & - & $0,05-0,1$ & - & - \\
\hline Fon:
\end{tabular}
Fonte: Faria (2013).

Os resultados obtidos apontaram que houve influência da posição dos emissores planos (tipo pastilha) dentro do tubo voltado para cima ou para baixo na resistência à obstrução dos gotejadores analisados. Quando instalado com o emissor para baixo, foram observados maiores níveis de obstrução, comparados aos mesmos modelos com os emissores voltado para cima. Segundo o autor, a norma deve especificar que os emissores sejam testados 
em ambas as condições de posicionamento. Também foi observado que emissores de menor vazão $\left(1,0-1,7 \mathrm{~L} \mathrm{~h}^{-1}\right)$ apresentaram maior sensibilidade à obstrução por partículas sólidas, quando comparado aos gotejadores de maiores vazões $\left(2,0-3,5 \mathrm{~L} \mathrm{~h}^{-1}\right)$, afirmando também que emissores com diferentes características geométricas apresentaram resistência diferenciadas à obstrução causada por partículas solidas em suspensão.

O IRSTEA tem adotado um procedimento de ensaio de obstrução há aproximadamente 40 anos, considerado pelos profissionais do instituto um método confiável. O protocolo de ensaio obedece as seguintes condições: o material de obstrução é originado de solo natural e preparado conforme procedimento estabelecido na norma ISO 11277 (2009), havendo destruição da matéria orgânica, dispersão da argila e peneiramento do solo, o ensaio é divido em quatro fases, em cada fase o sistema é submetido a 40 horas de funcionamento em regime intermitente, operando 8 horas por dia, ao longo de 5 dias. A cada 40 horas são acrescentado $125 \mathrm{mg} \mathrm{L}^{-1}$ de partículas com uma faixa de maior diâmetro. As faixas granulométricas adicionada em cada fase são: 1) 0 - $80 \mu \mathrm{m}$; 2) 80 - $120 \mu \mathrm{m}$; 3) 120 - $200 \mu \mathrm{m}$; 4) $200-500 \mu \mathrm{m}$.

A falta de um método padrão e confiável para ensaios de obstrução pode conduzir a resultados incoerentes. Emissores submetidos a ensaios que adotem procedimentos distintos podem apresentar diferentes comportamentos quanto a sensibilidade à obstrução. Desta forma, enquanto um emissor pode ser altamente sensível à obstrução para uma determinada condição de ensaio, em outra o mesmo pode se mostrar altamente resistente.

\subsection{Repetitividade e reprodutibilidade}

Validação de um método é um processo que fornece evidências, por meio de estudos, que garantem que a metodologia seja exata, reprodutível e que tenha variações sobre uma faixa específica, assegurando que os resultados das análises realizadas pela metodologia sejam confiáveis (INSTITUTO NACIONAL DE METROLOGIA, QUALIDADE E TECNOLOGIA - INMETRO, 2010). A precisão é adotado como um dos critérios para validação de um método e é utilizada para verificar a qualidade e a adequação de um determinado procedimento. A precisão representa a dispersão de resultados obtidos entre ensaios independentes, repetidos a partir de uma mesma amostra, amostras semelhantes ou padrões, em condições definidas. As duas formas mais comuns de expressá-la são por meio da repetitividade e a reprodutibilidade, sendo usualmente expressa pelo desvio padrão (INMETRO, 2010). 
O estudo de repetitividade expressa o grau de concordância entre resultados de medições sucessivas de um mesmo mensurando, conduzidas sob as mesmas condições de medição, denominadas como condições de repetitividade. Essas condições incluem mesmo procedimento de medição, mesmo observador, mesmo instrumento de medição utilizado sob as mesmas condições, mesmo local e repetições em curtos intervalos de tempo. A repetitividade pode ser avaliada de forma quantitativa por meio da dispersão dos resultados (EUROPEAN COOPERATION FOR ACREDITATION OF LABORATORIES - EAL, 1997; INMETRO, 2010), indicando a precisão dos dados sob condições em que os resultados de ensaio independentes são obtidos.

A reprodutibilidade pode ser definida como o grau de concordância entre resultados de medidas de um mesmo mensurando, realizadas sob diferentes condições de medição. Essas diferenças nas condições podem incluir princípio da medição, método de medição, observador, instrumento de medição, padrão de referência, local, condições de uso e tempo. A reprodutibilidade também pode ser avaliada de forma quantitativa por meio da dispersão dos resultados (EAL, 1997; INMETRO, 2010).

A variabilidade dos resultados é frequentemente inerente aos erros ou eventos desconhecidos que ocorrem durante a execução do ensaio. No caso de estudos de obstrução de emissores por partículas sólidas, a precisão dos resultados pode estar relacionada a variações na concentração de partículas no reservatório, variações nas características dos labirintos entre os emissores de mesmo modelo (como imperfeições ou defeitos de fabricação), obstrução causada por materiais de origem desconhecidas que podem entrar no sistema, obstrução por precipitados químicos, obstrução pela formação de biofilme, ou até mesmo pela ação combinada desses diferentes fatores. Desta forma, um procedimento de ensaio realizado diversas vezes pode apresentar resultados distintos entre as repetições, uma vez que fatores não controlados podem estar atuando e se comportando de forma distinta entre as repetições, causando variabilidade nos resultados dos ensaios.

Durante um procedimento de ensaio, é difícil identificar a ação desses fatores e quantificar a intensidade com que eles interferem nos resultados do ensaio. A falta de conhecimento de como cada componente atua em determinadas situações dificulta o controle de cada parâmetro, tornando os resultados pouco precisos. Dessa forma, necessita-se do desenvolvimento de metodologias que sejam adequadas para avaliação da sensibilidade dos emissores à obstrução, que permitam a identificação de possível atividade biológica no sistema, que possibilite identificar com precisão a concentração de partículas presentes no 
reservatório, e também que seja capaz de verificar a ocorrência de precipitação de íons durante os ensaios.

A determinação de um índice de repetitividade e reprodutibilidade para ensaios de obstrução de emissores são, na maioria das vezes, de difícil realização. Considerando-se que a maioria desses ensaios demandam grande quantidade tempo para ser executados, podendo levar semanas ou meses, obter um número de repetições suficiente para se determinar a precisão dos métodos levaria longos períodos, tornando-se uma tarefa difícil e economicamente inviável. 


\section{METODOLOGIA}

Os experimentos para avaliar o protocolo de ensaio do LERMI/IRSTEA proposto para elaboração da norma ISO foram conduzidos no Laboratório de Irrigação do Departamento de Engenharia de Biossistemas da Escola Superior de Agricultura "Luiz de Queiroz" (ESALQ USP).

\subsection{Gotejadores}

Foram avaliados quatro modelos de tubogotejadores com emissores convencionais (não compensantes), integrados, de formato plano (tipo pastilha). Foram escolhidas duas marcas de tubogotejador e dois modelos de cada marca, um de maior e outro de menor vazão (Tabela 4). Os quatro modelos de tubogotejadores avaliados apresentam diâmetro nominal de $17 \mathrm{~mm}$ e espaçamento entre emissores de 0,30 m, e foram operados sob pressão de 98,1 kPa. As vazões e as dimensões dos emissores selecionados são apresentados no esquema na Figura 1. Os dois emissores Drip-Tech apresentam estruturas e dimensões do labirinto semelhantes, variando apenas a profundidade do canal.


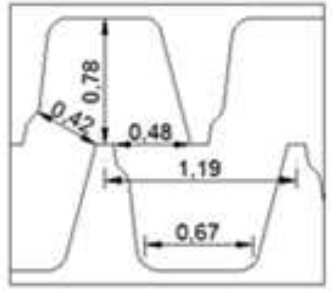

d)



e)

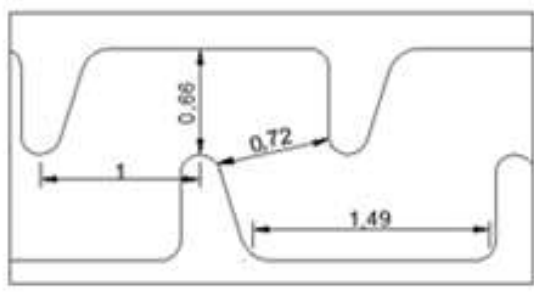

f)

Figura 1 - Esquema das características geométricas dos emissores Taldrip 0,6 L h${ }^{-1}$ (a); Taldrip 1,7 L h${ }^{-1}$ (b); Drip-Tech 1,6 $\mathrm{L} \mathrm{h}^{-1}$; e Drip-Tech 1,2 $\mathrm{L} \mathrm{h}^{-1}$ (c). Dimensões dos labirintos dos emissores Taldrip 0,6 $\mathrm{L} \mathrm{h}^{-}$ ${ }^{1}$ (d); Taldrip 1,7 L h${ }^{-1}$ (e); Drip-Tech 1,2 $\mathrm{L} \mathrm{h}^{-1}$; e Drip-Tech 1,6 L h${ }^{-1}$ (f) 
Tabela 4 - Características técnicas dos emissores selecionados

\begin{tabular}{ccccccc}
\hline Fabricante & Modelo & $\begin{array}{c}\text { Vazão nominal } \\
\left(\mathrm{L} \mathrm{h}^{-1}\right)\end{array}$ & $\begin{array}{c}\text { Comprimento } \\
\text { do emissor } \\
(\mathrm{mm})\end{array}$ & $\begin{array}{c}\text { Largura do } \\
\text { emissor }(\mathrm{mm})\end{array}$ & $\begin{array}{c}\text { Espessura } \\
\text { do emissor } \\
(\mathrm{mm})\end{array}$ & $\begin{array}{c}\text { Profundidade } \\
\text { do canal do } \\
\text { labirinto }(\mathrm{mm})\end{array}$ \\
\hline NaanDanJain & Taldrip & 1,70 & 32,6 & 6,0 & 2,4 & 0,71 \\
NaanDanJain & Taldrip & 0,60 & 32,6 & 6,0 & 2,4 & 0,42 \\
Drip-Plan & Drip-Tech & 1,60 & 30,1 & 8,4 & 3,1 & 0,64 \\
Drip-Plan & Drip-Tech & 1,20 & 30,1 & 8,4 & 3,1 & 0,54 \\
\hline
\end{tabular}

\subsection{Bancada de ensaios}

As avaliações foram realizadas na bancada para ensaios de obstrução de gotejadores presente no laboratório de irrigação. A bancada (Figura 2) apresenta um reservatório de polietileno de $250 \mathrm{~L}$ (com largura de $90 \mathrm{~cm}$ e profundidade de $52 \mathrm{~cm}$ ) acoplado a um conjunto motobomba (com potência de $3 \mathrm{CV}$, vazão máxima de $15 \mathrm{~m}^{3} \mathrm{~h}^{-1}$ e altura manométrica máxima de 46 m.c.a) que alimenta uma linha de derivação com bifurcações simétricas (Figura 3) responsável por distribuir a água uniformemente entre oito linhas laterais em paralelo e de igual comprimento (5 m). A estrutura é equipada com calhas metálicas instaladas em declive, responsáveis por conduzir de volta ao reservatório a água escoada pelos gotejadores e pelos finais de linha.

Um filtro de tela com elemento filtrante de abertura de $595 \mu \mathrm{m}$ (30 mesh) foi instalado na saída da motobomba com o objetivo de reter e evitar que partículas com diâmetro superior ao da areia aplicada entrassem nas linhas laterais. Esses materiais poderiam ser originados pelo processo de desgaste do rotor da bomba, em função do efeito abrasivo da areia, ou até mesmo pela presença de partículas sólidas que poderiam cair sobre a bancada durante os ensaios. Como medida preventiva à contaminação da água por materiais de origem externa, foi instalado lonas plásticas nas laterais e no teto da bancada, e o reservatório foi coberto com uma tampa.



Figura 2 - Esquema da bancada para ensaios de obstrução 


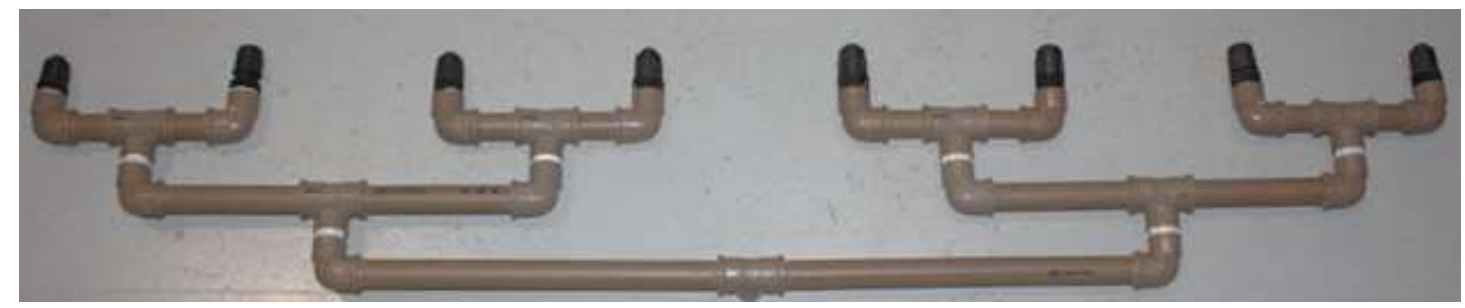

Figura 3 - Linha de derivação com bifurcações simétricas

Com o objetivo de manter as partículas sólidas em suspensão durante o ensaio foi instalado um agitador mecânico que manteve a água do reservatório em constante movimento. $\mathrm{O}$ agitador contou com um motor elétrico, com potência de $0,25 \mathrm{CV}$, acoplado a uma haste e uma hélice com diâmetro de $18 \mathrm{~cm}$, confeccionados em aço inoxidável, a fim de evitar oxidação e contaminação da mistura água/areia. A hélice foi instalada com distância de 11,5 cm do fundo do reservatório e a rotação de operação foi de $354 \mathrm{rpm}$, sendo suficiente para manter todas as partículas em suspensão.

A bancada de ensaios apresenta uma tubulação de retorno com um registo de gaveta para auxiliar no ajuste da pressão de operação e um sistema de distribuição de água na extremidade dessa tubulação. A água proveniente do retorno desagua na extremidade da bancada, contribuindo assim para o carregamento de partículas, evitando um eventual acúmulo de material na calha. Assim, a água é conduzida juntamente com as partículas para o reservatório.

\subsection{Escolha dos bocais para controle da vazão nas linhas laterais}

O controle da velocidade de escoamento da água nos tubos foi realizado por meio de bocais de pivô central instalados na extremidade dos tubos gotejadores. A fim de evitar acúmulo de partículas na bancada, os bocais foram instalados na parte mais alta das calhas, de modo que o volume de água escoado pelos bocais, ao percorrer a calha para retornar ao reservatório, contribuísse com o transporte das partículas que eventualmente pudessem acumular-se sobre a calha.

O diâmetro do bocal foi determinado pela eq. (1), utilizando os parâmetros de diâmetro interno dos tubos utilizados $(0,0155 \mathrm{~m})$, da velocidade de escoamento da água nos tubos $\left(1 \mathrm{~m} \mathrm{~s}^{-1}\right)$, do coeficiente de descarga do bocal $(0,89)$ e pressão de operação (10 m.c.a.). 


$$
D_{b}=D_{t} \sqrt{\frac{V}{C d \sqrt{2 g h}}}
$$

em que: $D_{b}$ - diâmetro do bocal (m);

$V$ - velocidade de escoamento da água no tubo $\left(\mathrm{m} \mathrm{s}^{-1}\right)$;

$D_{t}$ - diâmetro interno do tubo $(\mathrm{m})$;

$C_{d}$ - coeficiente de descarga do bocal (adimensional);

$g$ - aceleração da gravidade $\left(\mathrm{m} \mathrm{s}^{-2}\right)$; e,

$h$ - pressão no bocal (m.c.a.).

Pela eq. (1) foi determinado que o diâmetro do bocal deveria ser de 4,28 mm, sendo escolhido o bocal disponível com diâmetro mais próximo $(4,2 \mathrm{~mm})$. Após verificado o diâmetro necessário, foram escolhidos oito bocais que apresentaram as vazões mais próximas (coeficiente de variação de fabricação de 0,24\%). Na Figura 4 são apresentados os valores de vazão dos oito bocais escolhidos.

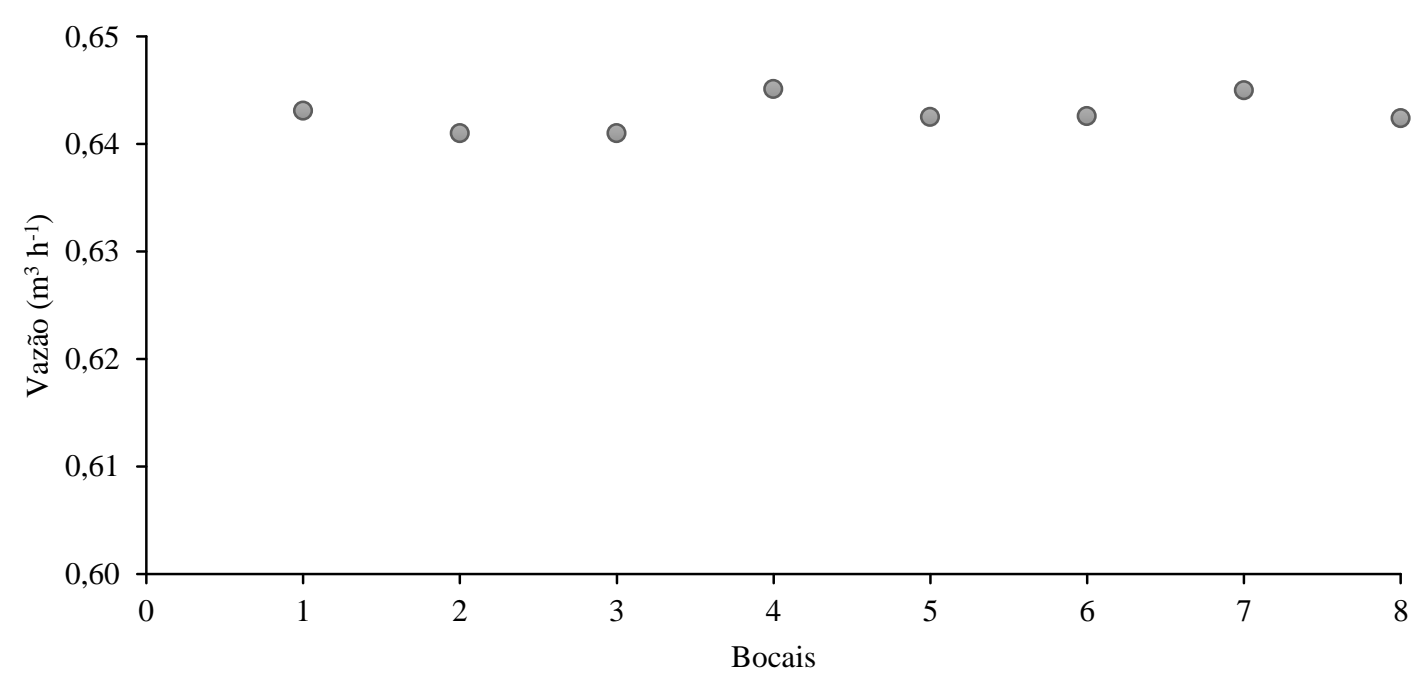

Figura 4 - Vazão dos bocais de pivô central selecionados para o controle da vazão nas laterais

\subsection{Dimensionamento do sistema de distribuição de água e recalque}

Baixas velocidades de escoamento da água contendo material sólido em suspensão podem induzir à sedimentação das partículas nos tubos, prejudicando o fluxo da água e reduzindo a concentração de areia no reservatório durante o ensaio. Para evitar esse efeito, os 
diâmetros dos tubos do sistema de distribuição e do sistema de recalque (Figura 5) foram dimensionados de forma que a velocidade fosse suficiente para manter as partículas suspensas. Para determinação do diâmetro adequado foi utilizada a eq. (2), proposta por Durand e Condolios (1952) apud Puig-Bargués e Lamm (2013), que estabelece a velocidade mínima de escoamento, também denominada velocidade crítica.

$$
V_{c}=F_{L} \sqrt{2 g D_{i}\left(\frac{\rho_{s}-\rho_{L}}{\rho_{L}}\right)}
$$

em que: $V_{c}$ - velocidade crítica $\left(\mathrm{m} \mathrm{s}^{-1}\right)$;

$F_{L}$ - fator de Durand (adimensional);

$g$ - aceleração da gravidade $\left(\mathrm{m} \mathrm{s}^{-2}\right)$;

$D_{i}$ - diâmetro interno do tubo $(\mathrm{m})$;

$\rho_{s}$ - massa específica da partícula $\left(\mathrm{kg} \mathrm{m}^{-3}\right) ; \mathrm{e}$,

$\rho_{L}-$ massa específica do líquido $\left(\mathrm{kg} \mathrm{m}^{-3}\right)$.

O fator $F_{L}$ é calculado pela eq. (3), apresentada por Schiller e Herbich (1991) apud Puig-Bargués e Lamm (2013).

$$
F_{L}=1,3 C_{\mathrm{V}}^{0,125}\left(1-e^{-6,9 d_{50}}\right)
$$

em que: $C_{\mathrm{V}}-$ concentração de partículas em base de volume (adimensional); e,

$d_{50}$ - diâmetro pelo qual passam cinquenta por cento das partículas ( $\left.\mathrm{mm}\right)$.

Foram utilizados como parâmetros de entrada nas equações: $C_{\mathrm{V}}=0,0189$ (500 ppm de material); $\mathrm{d}_{50}=0.25 \mathrm{~mm} ; \rho_{\mathrm{s}}=2650 \mathrm{~kg} \mathrm{~m}^{-3} ; \mathrm{e} \rho_{\mathrm{L}}=1000 \mathrm{~kg} \mathrm{~m}^{-3}$. Esses parâmetros correspondem à pior situação de operação, ou seja, a última fase de ensaio, em que é utilizado a maior granulometria e maior concentração de partículas. Os diâmetros nominais e internos dos tubos utilizados, velocidade crítica e velocidade de escoamento em cada trecho do sistema são apresentados na Tabela 5. 


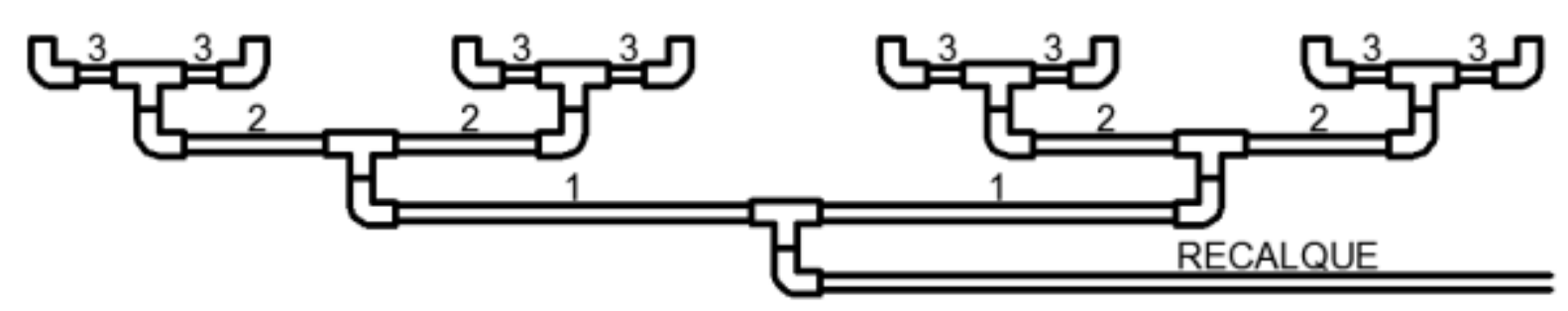

Figura 5 - Esquema dos trechos dimensionados do sistema de distribuição de água

Tabela 5 - Diâmetro de cada trecho (recalque e sistema de distribuição) com suas respectivas velocidades críticas e velocidade de escoamento

\begin{tabular}{ccccc}
\hline Trecho & $\begin{array}{c}\text { Diâmetro nominal do } \\
\text { tubo }(\mathrm{mm})\end{array}$ & $\begin{array}{c}\text { Diâmetro interno do tubo } \\
(\mathrm{mm})\end{array}$ & $\begin{array}{c}\mathrm{V}_{\mathrm{c}} \\
\left(\mathrm{m} \mathrm{s}^{-1}\right)\end{array}$ & $\begin{array}{c}\text { Velocidade de } \\
\text { escamento }\left(\mathrm{m} \mathrm{s}^{-1}\right)\end{array}$ \\
\hline Recalque & 32 & 27,8 & 0,62 & 2,49 \\
1 & 25 & 21,6 & 0,54 & 2,06 \\
2 & 20 & 17 & 0,48 & 1,66 \\
3 & 20 & 17 & 0,48 & 0,83 \\
\hline
\end{tabular}

\subsection{Uniformidade de distribuição de água do sistema}

Para verificar a uniformidade de distribuição de água entre as linhas, pelo sistema de distribuição implantado, foi realizado um procedimento de ensaio que consistiu na determinação da vazão de cada linha utilizando tubos de polietileno lisos (sem gotejadores inseridos). Após a instalação dos bocais e a estabilização da vazão e pressão de operação do sistema, coletou-se, por um tempo cronometrado, aproximadamente $16 \mathrm{~L}$ de água emitida pelo bocal de cada linha lateral. A determinação da vazão foi realizada pela eq. (2) por meio da massa de água coletada, massa específica da água e tempo de coleta. Na Figura 6 são apresentadas as médias de quatro repetições para cada linha. O CV da vazão entre as linhas foi de $0,48 \%$.

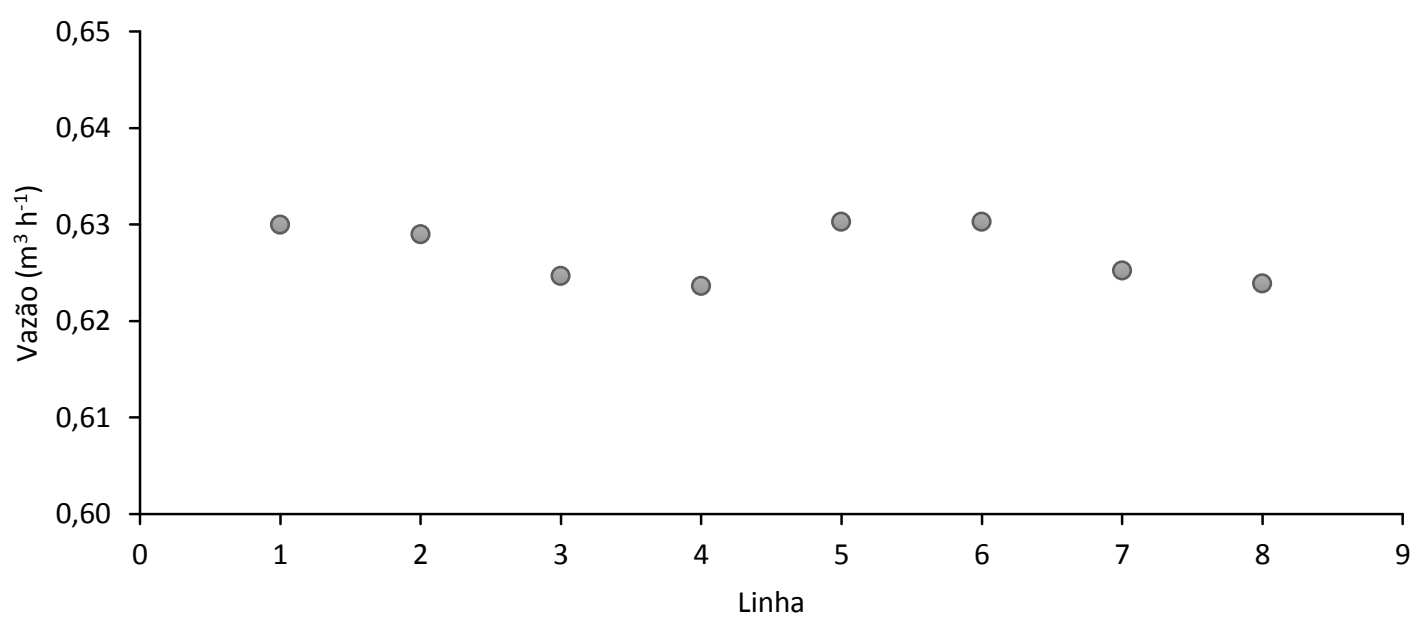

Figura 6 - Vazão das oito linhas laterais utilizando tubos de polietileno liso 


\subsection{Partículas sólidas utilizadas para os ensaios de obstrução}

Segundo o procedimento que está sendo proposto como norma, e que é utilizado pelo LERMI/IRSTEA, o composto deve ser constituído por uma mistura de areia, silte e argila devendo-se utilizar partículas sólidas naturalmente encontradas em água de irrigação, a fim de que o procedimento reproduza condições de campo. Dessa forma, na realização dos ensaios foi utilizado solo disponível na ESALQ como fonte de partículas para os experimentos, que apresenta $60,56 \%$ de argila, $12,49 \%$ de silte e $26,95 \%$ de areia, classificado como argila pesada pelo triângulo de classificação textural segundo Instituto Agronômico de Campinas (IAC) (CAMARGO et al., 2009). A curva granulométrica do solo é apresentada na Figura 7.

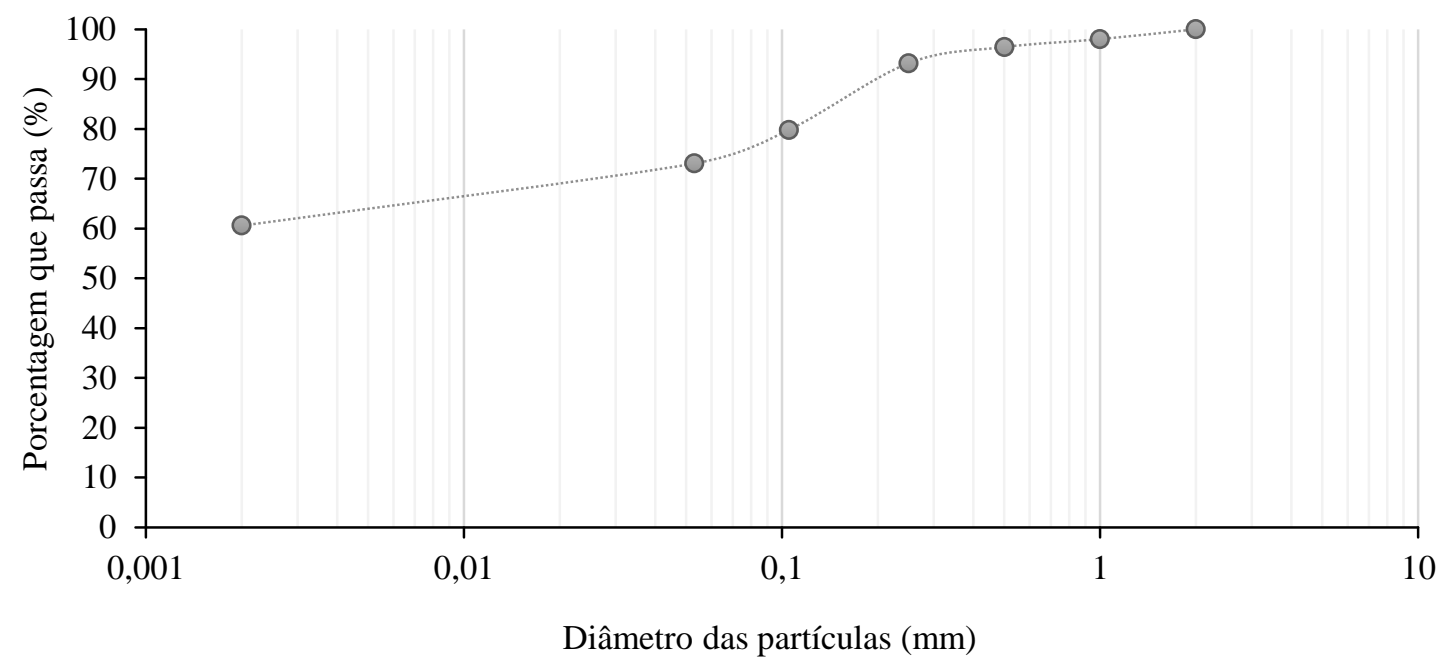

Figura 7 - Curva granulométrica do solo utilizado para obtenção do material de obstrução

Antes da elaboração do material utilizado para obstrução, o solo coletado passou por um processo de preparação realizado conforme a norma ISO 11277 (2009) que estabelece o procedimento para análise granulométrica de solo, adotando métodos de destruição de matéria orgânica e dispersão da argila. Os métodos utilizados nesse procedimento permitem obter desagregação e dispersão de partículas finas, evitando que no momento do peneiramento do solo sejam retidas partículas que sejam formadas por agregados de partículas menores. Os passos detalhados sobre o procedimento realizado são descritos a seguir.

Após coletado, o solo foi seco ao ar, destorroado e peneirado em peneira com abertura de $2 \mathrm{~mm}$. A partir do material que passou pela peneira foram tomadas várias amostras com cerca de $20 \mathrm{~g}$ cada e alocadas em béqueres. Em seguida foi adicionado à cada amostra $30 \mathrm{ml}$ de água para o umedecimento do solo, e depois adicionado $30 \mathrm{ml}$ de peróxido de hidrogênio 
$\left(\mathrm{H}_{2} \mathrm{O}_{2}\right)$ com $30 \%$ de concentração, para destruição da matéria orgânica. O conteúdo dos béqueres foi agitado com bastão de vidro e coberto com vidro de relógio, permanecendo em repouso no período noturno durante 15 horas. No dia seguinte os béqueres foram alocados em uma placa aquecedora (Figura 8a) tendo a temperatura de aquecimento elevada gradualmente até atingir valor entre $105^{\circ} \mathrm{C}$ e $110^{\circ} \mathrm{C}$, permanecendo até que o sinal de borbulhas devido a decomposição do $\mathrm{H}_{2} \mathrm{O}_{2}$ tivesse cessado. Posteriormente foi adicionado a cada amostra $25 \mathrm{ml}$ de solução de cloreto de cálcio $\left(\mathrm{CaCl}_{2}\right)$ com concentração de $1 \mathrm{~mol} \mathrm{~L} \mathrm{~L}^{-1}$, para realizar a floculação dos minerais, e adicionado água até que o volume total chegasse a $250 \mathrm{ml}$, devendo ficar em repouso para sedimentação do material. Após a sedimentação das partículas minerais, os resíduos da decomposição da matéria orgânica foram eliminados pelo sifonamento do sobrenadante. Este procedimento foi realizado até que a condutividade elétrica (CE) do sobrenadante fosse inferior a $0,4 \mathrm{dS} \mathrm{m}^{-1}$, sendo acrescentado água deionizada até se atingir o volume inicial.

Após a destruição da matéria orgânica foi realizada a remoção de sais solúveis e gesso para que não interferissem na fase de dispersão. Para esse procedimento, o material foi colocado em um recipiente com fração solo:água de 1:4 do volume, e em seguida, colocados em agitador horizontal tipo shaker (Figura 8b) por um período de uma hora. Depois de retirados do agitador, os recipientes permaneceram em repouso até que as partículas sedimentassem. Após a sedimentação, era determinada a CE da solução sobrenadante. Quando o valor da condutividade era superior ao estabelecido pela norma $\left(0,4 \mathrm{dS} \mathrm{m}^{-1}\right)$, o sobrenadante era eliminado, adicionado novamente água deionizada e agitado por mais uma hora, sendo este procedimento realizado até que a $\mathrm{CE}$ adequada fosse atingida.

Após atingida a condutividade estabelecida pela norma, foi realizado a etapa de dispersão. O agente dispersante sugerido pela norma é a solução com $33 \mathrm{~g}$ de hexametafosfato de sódio $\left(\mathrm{NaPO}_{3}\right)$ e $7 \mathrm{~g}$ de carbonato de sódio $\left(\mathrm{Na}_{2} \mathrm{CO}_{3}\right)$ dissolvidos em $1 \mathrm{~L}$ de água destilada. No entanto, a norma permite a utilização de outro agente dispersante em função de diferentes características existente entre os solos. Para os solos do Brasil, Camargo et al. (2009) sugere a utilização de uma solução com 20 g hidróxido de sódio $(\mathrm{NaOH})$ e 50 g de $\mathrm{NaPO}_{3}$ dissolvidos em $5 \mathrm{~L}$ de água destilada, sendo essa metodologia indicada pelo IAC e adotada nos laboratórios de análise física de solo no país. Para este procedimento foi adicionado à cada amostra $100 \mathrm{ml}$ de agente dispersante. Posteriormente, os recipientes foram novamente colocados no agitador horizontal e agitados por um período de 18 horas. Após o processo de agitação, o conteúdo dos recipientes foi lavado com jato de água destilada em peneira com abertura de 0,044 mm (Figura 8c). Tanto o material que ficou retido na peneira (areia e parte 
de silte correspondentes a faixa granulométrica de 2 a $0,044 \mathrm{~mm}$ ), quanto o material que passou pela peneira (argila e parte de silte com granulometria menor que $0,044 \mathrm{~mm}$ ) foram secos em estufa a $105^{\circ} \mathrm{C}$ até atingisse peso constante.

Após a secagem, o material com granulometria inferior a 0,44 $\mathrm{mm}$ apresentou a formação de grandes agregados, necessitando ser destorroado e peneirado novamente na peneira de $0,044 \mathrm{~mm}$. O material retido na peneira, após a secagem, foi submetido a um processo de peneiramento para separação em diversas faixas granulométricas (Figura 8d). No Brasil não foram encontradas peneiras com aberturas iguais àquelas sugeridas pelo protocolo de ensaios francês. Assim sendo, a Tabela 6 lista as faixas granulométricas adotadas pelo LERMI/IRSTEA e as utilizadas no presente experimento.

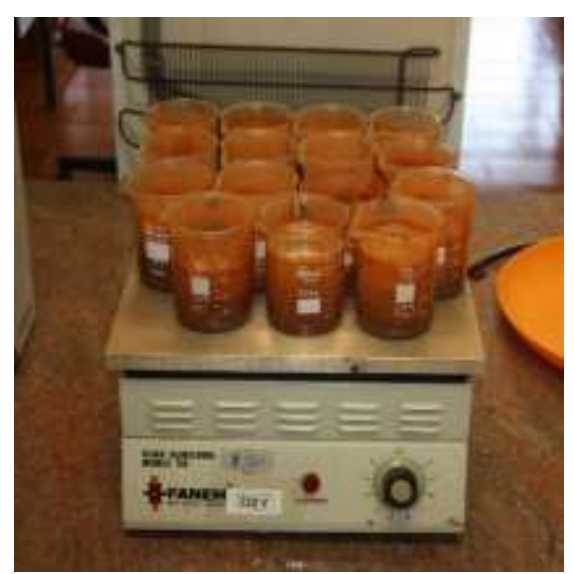

a)

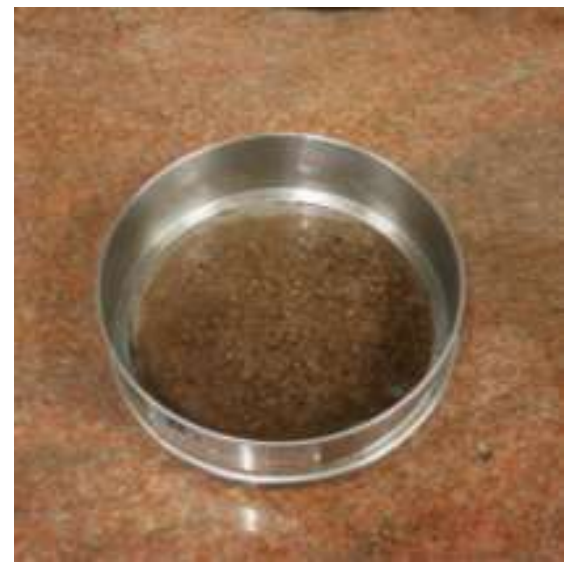

c)



b)

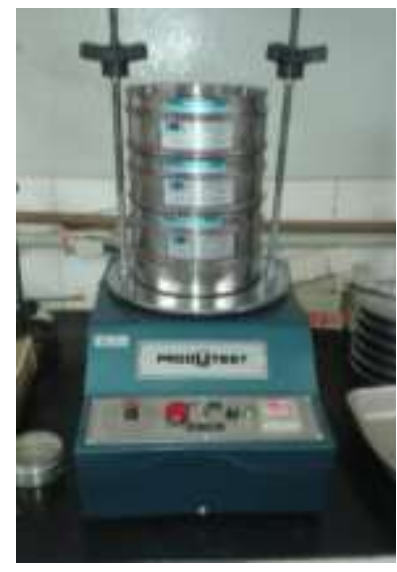

d)

Figura 8 - Béqueres sobre placa aquecedora (a); recipientes contendo solo com agente dispersante no agitador horizontal tipo shaker (b); Peneira de $44 \mu \mathrm{m}$ após a lavagem das partículas (c); e agitador com peneiras para separação das partículas em diferentes faixas granulométricas (d) 
Tabela 6 - Faixas granulométricas utilizadas pelo LERMI e faixas granulométricas utilizadas no experimento para cada etapa

\begin{tabular}{ccc}
\hline Faixa & $\begin{array}{c}\text { Faixa granulométrica utilizada pelo } \\
\text { LERMI/IRSTEA }(1)(\mu \mathrm{m})\end{array}$ & $\begin{array}{c}\text { Faixa granulométrica a ser utilizada no } \\
\text { experimento }(\mu \mathrm{m})\end{array}$ \\
\hline 1 & $0-80$ & $0-75$ \\
2 & $80-120$ & $75-125$ \\
3 & $120-200$ & $125-212$ \\
4 & $200-500$ & $212-500$ \\
\hline
\end{tabular}

(1) Laboratoire d'Études et Recherches sur les Matériels d'Irrigation/Institut national de recherche en sciences et technologies pour l'environnement et l'agriculture (LERMI/IRSTEA)

As peneiras granulométricas foram sobrepostas possibilitando a separação das partículas em 15 intervalos (Tabela 7). Após classificadas, cada faixa granulométrica foi obtida por meio da combinação do material que ficou retido em cada peneira utilizando a eq. (4). A quantidade de partículas, separada por cada peneira, adicionada para formar cada faixa foi proporcional à diferença entre a máxima e a mínima granulometria que ficou retida na peneira. Por exemplo, a faixa $2(75$ a $125 \mu \mathrm{m})$ foi composta pela combinação das partículas retidas nas peneiras $9(106$ a $125 \mu \mathrm{m}), 10(90$ a $106 \mu \mathrm{m})$ e $11(75$ a $90 \mu \mathrm{m})$. A peneira 9 retém partículas com intervalo de $19 \mu \mathrm{m}$ de diâmetro, valor superior à 16 e $15 \mu \mathrm{m}$ retidas pelas peneiras 10 e 11 respectivamente. Com diferença de $50 \mu \mathrm{m}$ entre a maior e a menor granulometria a ser utilizada na faixa $2(75$ a $125 \mu \mathrm{m})$, o intervalo das partículas retidas pela peneira 9 representa maior proporção, sendo então responsável por contribuir com $38 \%$ da concentração da faixa granulométrica enquanto que as peneiras 10 e 11 contribuem com 32 e $30 \%$ respectivamente. A curva de distribuição granulométrica do material de obstrução utilizado nos ensaios é apresentado na Figura 9.

$$
C P_{i}=\frac{D F P_{i}-D I P_{i}}{D F F_{j}-D I F_{j}} 100
$$

em que: $C P$ - contribuição da peneira $i$ na concentração da faixa granulométrica (\%);

$i$ - número da peneira;

$D F P$ - diâmetro final de partícula retido na peneira $(\mu \mathrm{m})$;

$D I P$ - diâmetro inicial de partícula retido na peneira $(\mu \mathrm{m})$;

$D F F$ - diâmetro final de partícula na faixa granulométrica $(\mu \mathrm{m})$;

$D I F$ - diâmetro inicial de partícula na faixa granulométrica $(\mu \mathrm{m})$; e,

$j$ - número da faixa granulométrica. 
Exemplos:

$$
\begin{gathered}
\text { Peneira } 9 \\
C P_{9}=\frac{125-106}{125-75} 100 \\
C P_{9}=38 \%
\end{gathered}
$$

Peneira 10

$$
\begin{gathered}
C P_{10}=\frac{106-90}{125-75} 100 \\
C P_{10}=32 \%
\end{gathered}
$$

\begin{tabular}{|c|c|c|c|c|}
\hline $\begin{array}{c}\text { Faixa } \\
\text { granulométrica } \\
(\mu \mathrm{m})\end{array}$ & $\begin{array}{l}\mathrm{N}^{\mathrm{o}} \mathrm{da} \\
\text { peneira }\end{array}$ & $\begin{array}{l}\text { Malha da } \\
\text { peneira } \\
\text { (ASTM) }\end{array}$ & $\begin{array}{l}\text { Intervalo de diâmetro de partículas } \\
\text { retidas por cada peneira }(\mu \mathrm{m})\end{array}$ & $\begin{array}{c}\text { Contribuição do intervalo } \\
\text { na faixa granulométrica } \\
(\%)\end{array}$ \\
\hline \multirow{5}{*}{$500-212$} & 1 & 40 & $425 \leq$ int. $<500$ & 26,04 \\
\hline & 2 & 45 & $355 \leq$ int. $<425$ & 24,31 \\
\hline & 3 & 50 & $300 \leq$ int. $<355$ & 19,10 \\
\hline & 4 & 60 & $250 \leq$ int. $<300$ & 17,36 \\
\hline & 5 & 70 & $212 \leq$ int. $<250$ & 13,19 \\
\hline \multirow{3}{*}{$212-125$} & 6 & 80 & $180 \leq$ int. $<212$ & 36,78 \\
\hline & 7 & 100 & $150 \leq$ int. $<180$ & 34,48 \\
\hline & 8 & 120 & $125 \leq$ int. $<150$ & 28,74 \\
\hline \multirow{3}{*}{$125-75$} & 9 & 140 & $106 \leq$ int. $<125$ & 38,00 \\
\hline & 10 & 170 & $90 \leq$ int. $<106$ & 32,00 \\
\hline & 11 & 200 & $75 \leq$ int. $<90$ & 30,00 \\
\hline \multirow{4}{*}{$75-0$} & 12 & 230 & $75 \leq$ int. $<75$ & 16,00 \\
\hline & 13 & 270 & $53 \leq$ int. $<63$ & 13,33 \\
\hline & 14 & 325 & $45 \leq$ int. $<53$ & 10,67 \\
\hline & 15 & Fundo & $<45$ & 60,00 \\
\hline
\end{tabular}

Peneira 11

$$
\begin{gathered}
C P_{11}=\frac{90-75}{125-75} 100 \\
C P_{11}=30 \%
\end{gathered}
$$

Tabela 7 - Peneiras utilizadas para separação dos intervalos de diâmetro de partículas e contribuição de cada intervalo na composição da faixa granulométrica do material nos ensaios de obstrução



Figura 9 - Curva de distribuição granulométrica do material de obstrução utilizado para os ensaios experimentais 


\subsection{Ensaios}

Durante os ensaios foi utilizada água destilada, com o objetivo de diminuir a possibilidade da água conter compostos que favorecem a obstrução dos emissores por ação química ou biológica. $\mathrm{O} \mathrm{pH}$ da água foi monitorado diariamente ao fim do ensaio utilizando pHmetro de bancada. A temperatura da água foi monitorada durante a coleta, para fins de correção da vazão emitida pelos gotejadores.

Antes da adição de partículas sólidas à água em cada ensaio, era determinada a vazão inicial dos emissores, utilizada como referência na determinação da redução da vazão devido a obstrução. Também foi realizado um procedimento de desinfecção da bancada, que consistia na operação do sistema por cerca de três horas com uma solução de água destilada contendo 2 ppm de cloro livre, foi utilizado como fonte de cloro livre o hipoclorito de sódio $(\mathrm{NaOCl})$. Essa medida foi adotada com a finalidade de evitar que o procedimento de ensaio iniciasse com atividade de microrganismos que pudessem interferir no desempenho dos emissores.

A pressão de operação dos tubogotejadores foi monitorada por meio de um manômetro digital instalado no início de uma das linhas laterais. A velocidade de escoamento nos tubos foi de $1 \mathrm{~m} \mathrm{~s}^{-1}$, estabelecida pela metodologia adotada. Cada ensaio de obstrução teve duração de quatro semanas e foi divido em quatro fases. Em cada uma, o sistema foi submetido a 40 horas de funcionamento em regime intermitente, operando por oito horas diárias ao longo de cinco dias. Em cada fase as concentrações e as faixas granulométricas das partículas sólidas presentes no reservatório foram controladas, conforme especificado na Tabela 8.

Tabela 8 - Distribuição da concentração das faixas granulométricas em cada etapa

\begin{tabular}{ccccccc}
\hline & & \multicolumn{4}{c}{ Faixa granulométrica das partículas $(\mu \mathrm{m})$} & \multirow{2}{*}{$\begin{array}{c}\text { Concentração total } \\
\left(\mathrm{mg} \mathrm{L}^{-1}\right)\end{array}$} \\
\cline { 3 - 5 } Fase & Tempo (h) & $<75$ & $75-125$ & $125-212$ & $212-500$ & \\
\cline { 3 - 5 } & & \multicolumn{4}{c}{ Concentração de partículas $\left(\mathrm{mg} \mathrm{L}^{-1}\right)$} & - \\
2 & 125 & - & - & - & 250 \\
3 & $80-80$ & 125 & 125 & - & - & 375 \\
4 & $120-160$ & 125 & 125 & 125 & 125 & 500 \\
\hline
\end{tabular}

As oito linhas paralelas foram operadas simultaneamente com quatro modelos, resultando em 32 emissores de cada modelo instalados. Foram monitorados 26 emissores para cada modelo, sendo que a norma ABNT NBR ISO 9261 (ASSOCIAÇÃO BRASILEIRA DE NORMAS TÉCNICAS - ABNT, 2006), que especifica os métodos de ensaio de desempenho hidráulico de emissores de irrigação, estabelece que o número mínimo de emissores a serem monitorados sejam 25. Para escolha dos emissores monitorados, foram excluidos o primeiro e 
o ultimo emissor de cada linha, e ainda um emissor escolhido de forma aleatória ao longo da linha.

A vazão dos gotejadores foi monitorada ao fim de cada dia de ensaio (após as oito horas de funcionamento), pela medição da massa de água escoada em cada emissor e coletada manualmente utilizando coletores de alumínio (Figura 10). Para facilitar a coleta e evitar que as gotas escorressem pelo tubo foi instalado barbantes que conduziam a água diretamente ao coletor. O valor da vazão para cada emissor foi obtido pela eq. (5) utilizando a massa coletada em cada emissor num tempo igual a 30 min e a massa especifica da água, corrigida pela eq. (6).

$$
q=\frac{m 60}{1000 t \rho}
$$

em que: $q$ - vazão do emissor $\left(\mathrm{L} \mathrm{h}^{-1}\right)$;

$m$ - massa de água coletada $(\mathrm{g})$;

$t$ - tempo de coleta $(\mathrm{min})$;

$\rho$ - massa especifica da água $\left(\mathrm{kg} \mathrm{m}^{-3}\right)$.

$$
\rho=-0,00361 T^{2}-0,06383 T+1000,4342
$$

em que: $T$ - temperatura da água $\left({ }^{\circ} \mathrm{C}\right)$.

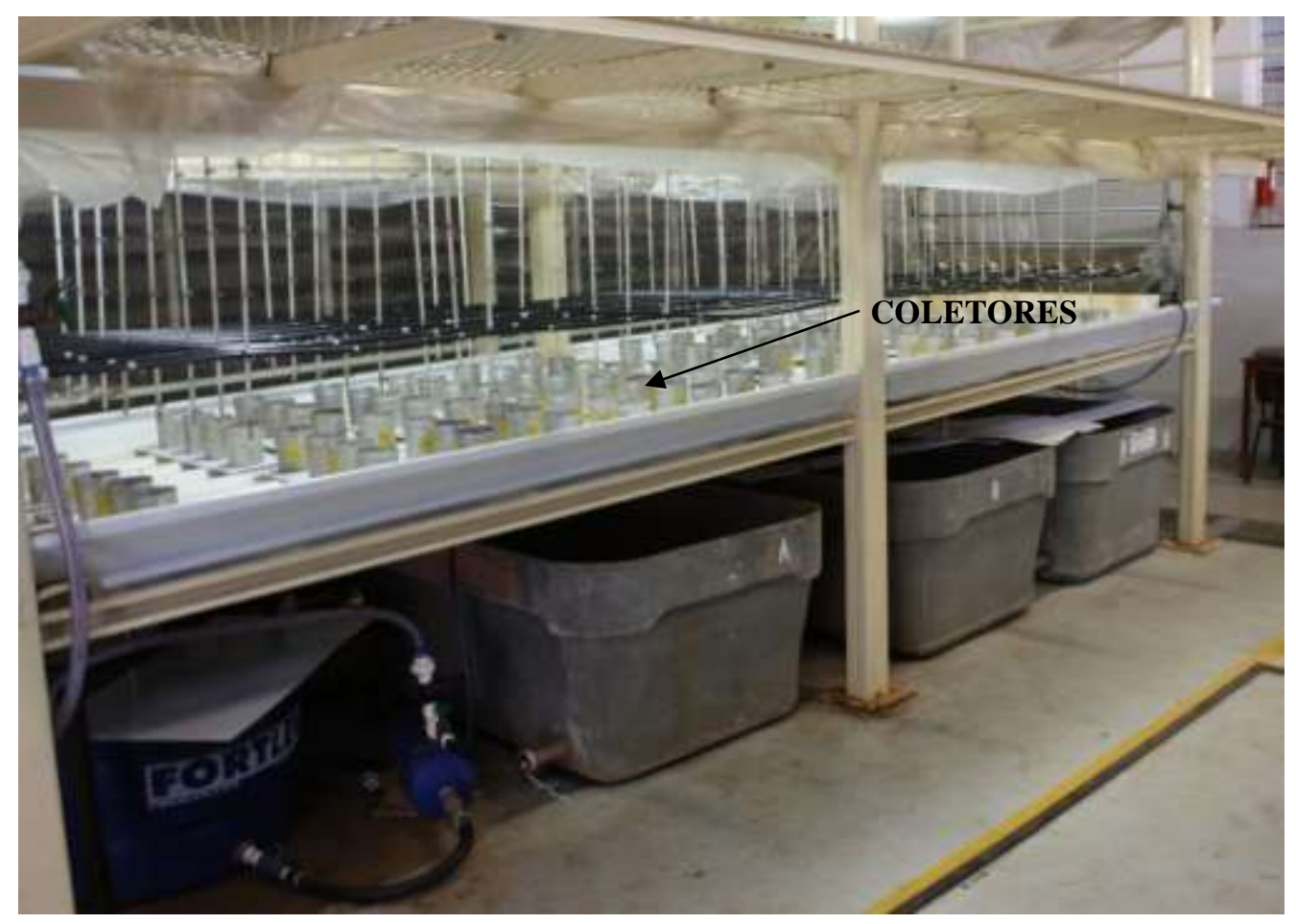

Figura 10 - Bancada de ensaio e coletores utilizados para monitoramento da vazão 
Foram realizadas três repetições do ensaio utilizando a mesma estrutura, os mesmos modelos de tubogotejadores, e água com as mesmas características. Ao término da quarta etapa de cada repetição, os tubogotejadores foram substituídos por tubos novos e a bancada de ensaio foi lavada visando manter as mesmas condições durantes das três repetições. A duração total dos experimentos foi de três meses.

\subsection{Avaliação da sensibilidade de gotejadores à obstrução}

A sensibilidade dos emissores à obstrução foi avaliada por meio da proporção de redução da vazão dos emissores durante o tempo de ensaio. Foi utilizado como critério para caracterização da obstrução, a redução de $25 \%$ da vazão média do grupo de emissores estudados. O grau de obstrução dos emissores foi obtido por meio da eq. (7) (WEI et al., 2008). Esta equação não é indicada para aplicação em estudos destinados a avaliação de gotejadores autocompensantes, uma vez que esse tipo de emissores podem apresentar comportamento diferenciado. Quando submetidos a condições de operação com água contendo partículas sólidas em suspensão, esses emissores podem sofrer aumento de vazão devido ao acúmulo de partículas entre a câmara e a membrana elástica, responsável pelo controle da vazão do emissor, causando um aumento da vazão (FARIA, 2013) e fazendo com que a média de um determinado número de emissores obstruídos e não obstruídos seja próximo a vazão inicial. A avaliação do protocolo de ensaio de obstrução foi realizada por meio da utilização de gráficos contendo o grau de obstrução para cada dia de ensaio em cada fase e para cada modelo de emissor. Pelos gráficos foi avaliado a variabilidade entre os resultados.

$$
G O=100\left(1-\frac{\sum_{i=1}^{n} q_{i}}{n \bar{q}}\right)
$$

em que: $G O$ - grau de obstrução (\%);

$q_{i}$ - vazão atual o i-ésimo emissor avaliado $\left(\mathrm{L} \mathrm{h}^{-1}\right)$;

$n$ - número de emissores avaliados (adimensional); e,

$\bar{q}$ - média da vazão inicial do modelo de emissor para uma dada pressão de operação $\left(\mathrm{L} \mathrm{h}^{-1}\right)$. 


\section{RESULTADOS E DISCUSSÃO}

\subsection{Ensaios preliminares}

O grau de obstrução e o número de emissores obstruídos para cada modelo, em cada dia de ensaio, nas quatro fases são apresentados na Figura 11. A figura também exibe o valor crítico de $25 \%$ para o grau de obstrução, representado pelas linhas pontilhadas na horizontal. Quando o grau de obstrução é superior a esse critério, o lote de emissores avaliados é considerado obstruído.

Nessa primeira execução, os 26 emissores dos quatro modelos estudados foram obstruídos por completo antes do término do ensaio. Pela Figura 11, é possível observar que o grau de obstrução aumenta gradualmente à cada dia de ensaio em todos os modelos, assim como o número de emissores obstruídos.

Para o modelo Drip-Tech 1,2 $\mathrm{L} \mathrm{h}^{-1}$ (Figura 11a) o grau de obstrução dos emissores atingiu o limite de $25 \%$ no início da segunda fase e continuou aumentando gradualmente, iniciando a terceira fase de ensaio com todos os emissores obstruídos por completo. O grau de obstrução dos emissores Drip-Tech 1,6 L h${ }^{-1}$ (Figura 11b) atingiu o limite critico de $25 \%$ logo na primeira fase de ensaio. Tanto o grau de obstrução como o número de emissores obstruídos aumentaram gradualmente até o fim da segunda fase, iniciando a fase seguinte com os 26 emissores totalmente obstruídos.

O modelo Taldrip $0,6 \mathrm{~L} \mathrm{~h}^{-1}$ (Figura 11c) foi o primeiro a atingir o critério de obstrução, ocorrendo logo no primeiro dia de ensaio, sendo totalmente obstruído na primeira fase. Já o modelo Taldrip 1,7 L h ${ }^{-1}$ (Figura 11d) apresentou grau de obstrução inferior ao limite crítico somente até o meio da segunda fase de ensaio com obstrução total dos emissores na terceira fase. 
(a)

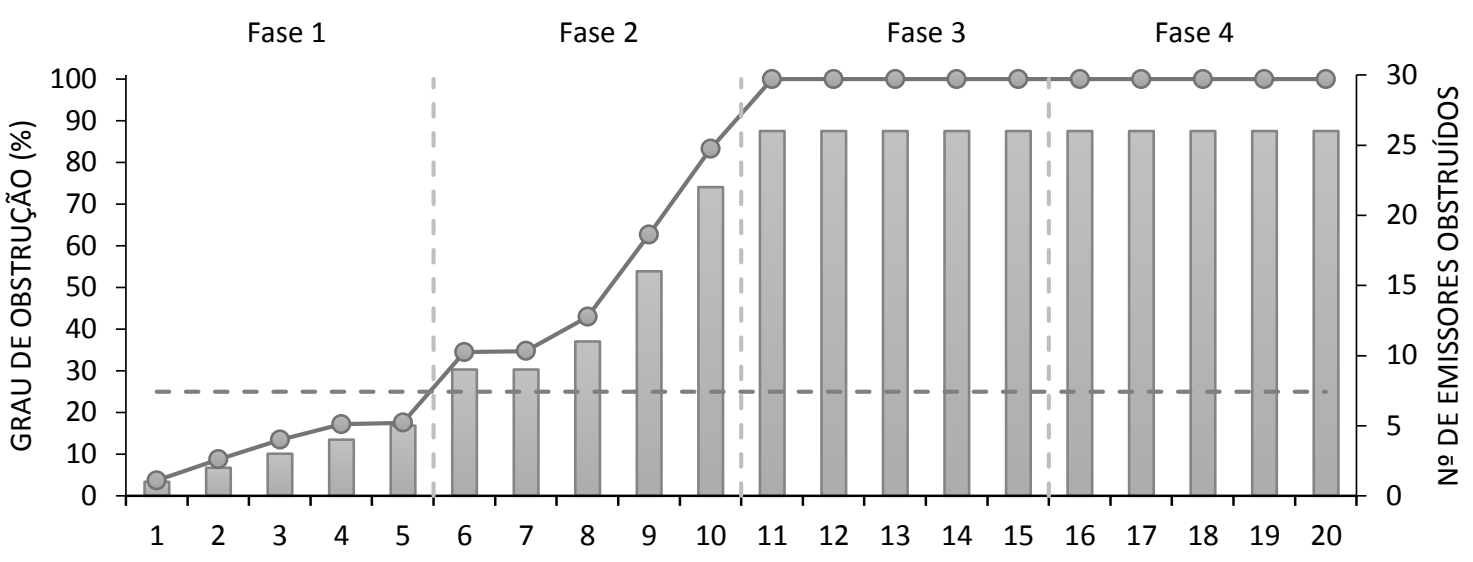

(b)

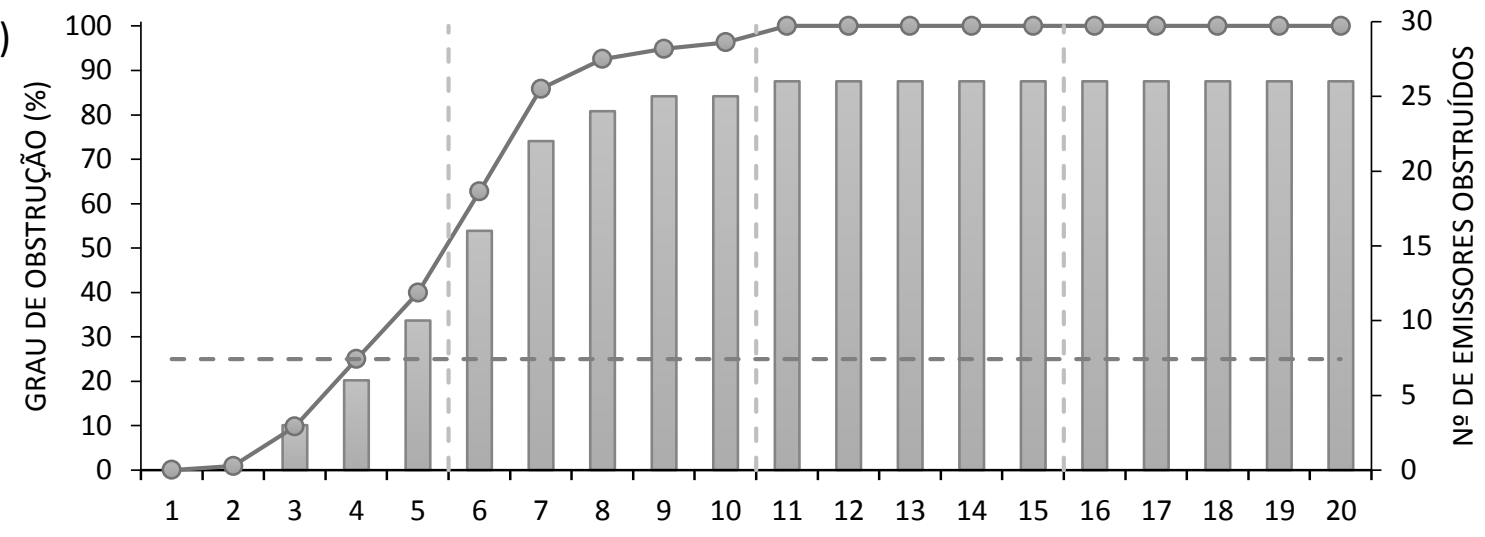

(c)

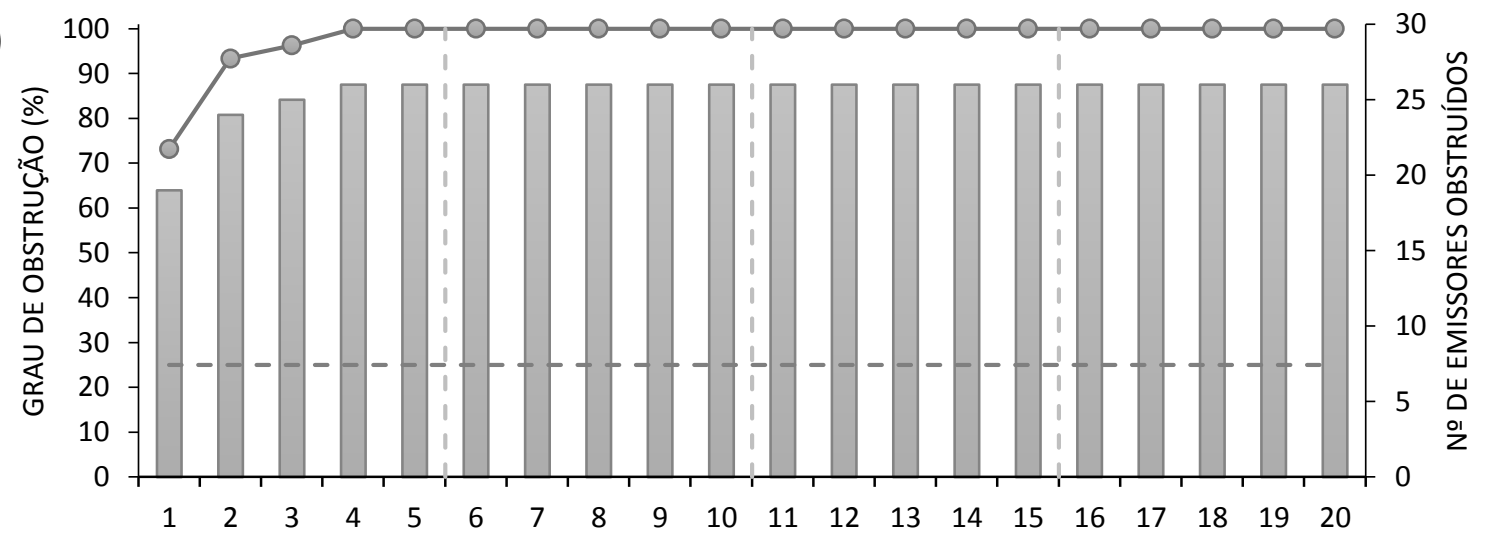

(d)

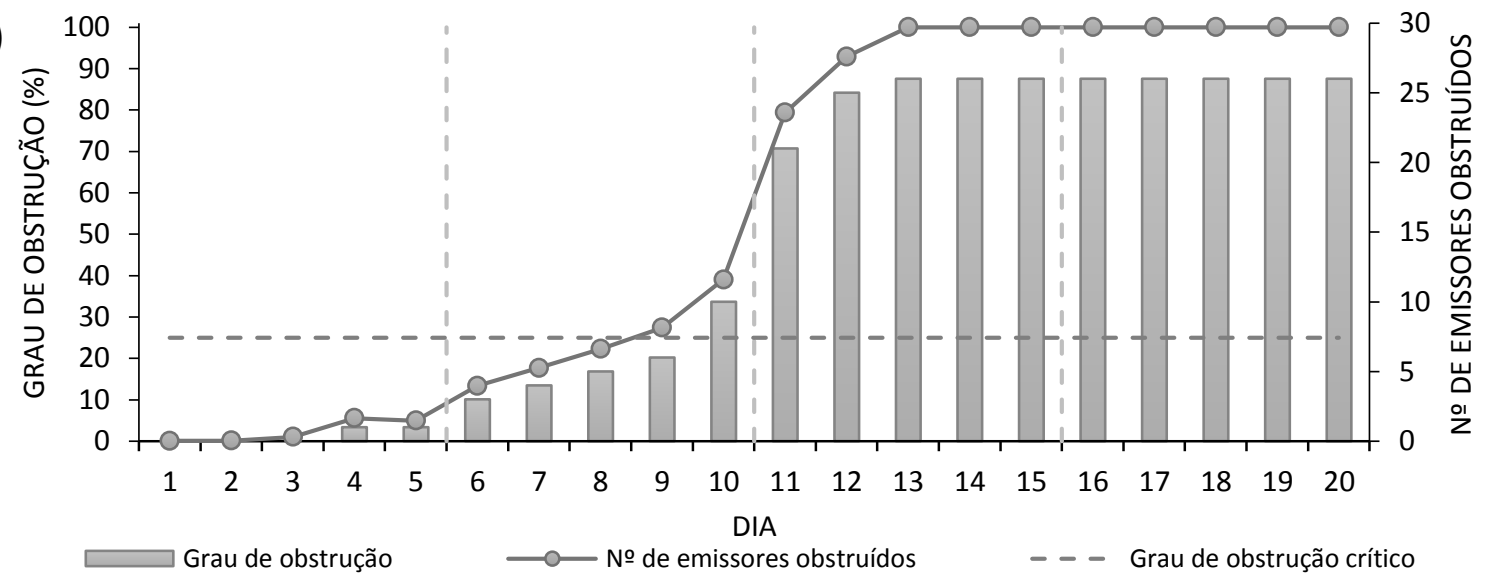

Figura 11 - Grau de obstrução e número de emissores obstruídos ao longo dos ensaios nas quatro fases: (a) DripTech 1,2 L h ${ }^{-1}$; (b) Drip-Tech 1,6 $\mathrm{L} \mathrm{h}^{-1}$; (c) Taldrip $0,6 \mathrm{~L} \mathrm{~h}^{-1}$; e, (d) Taldrip 1,7 $\mathrm{L} \mathrm{h}^{-1}$ 
Ao fim do ensaio, os emissores foram abertos para analisar as regiões de acúmulo de partículas nos labirintos. Foi observado que além das partículas utilizadas para obstrução, havia também presença de materiais filamentosos formando uma espécie de rede ou malha que segurava as partículas (Figura 12a), fenômeno que explica a obstrução precoce dos emissores. Na tentativa de identificar a origem do problema, foram realizadas fotos por microscopia eletrônica de varredura (MEV) do material no interior do labirinto (Figuras 12b e 12c). Inicialmente suspeitava-se que a origem do material indesejado fosse raízes, fungos ou algas. No entanto, pelos resultados da microscopia foram eliminadas essas hipóteses, sendo que o material apresentava características distintas de materiais orgânicos. Com isso, surgiram mais três hipóteses para a origem do material: 1) fibras do tecido que estava sendo utilizado para secagem dos coletores, realizada para redução do erro na mensuração da massa; 2) fibras dos barbantes de algodão utilizados para condução da água emitida pelos emissores até os coletores; e 3) fita veda rosca utilizada nas conexões roscáveis do sistema hidráulico. Foram coletadas amostras desses materiais e realizados fotos por MEV a fim de comparar com o material encontrado no interior do emissor (Figuras 12c, 12d, 12e). Ainda não se sabe ao certo a origem desse material, mas pelas imagens obtidas pela $\mathrm{MEV}$, o material que mais se assemelha as características estruturais é o tecido utilizado na secagem dos coletores. No entanto, a hipótese de que o material possa ser originado dos barbantes utilizados na condução da água não pode ser eliminada. A possibilidade de ser a fita veda rosca foi descartada, já que essa apresenta características muito distintas do material encontrado no emissor.

Os coletores eram secos internamente, antes da coleta da água, e externamente antes da pesagem, para retirada do excesso de água devido os respingos das gotas que caiam sobre a bancada durante a coleta. É possível que no momento em que os coletores eram secos, o tecido desprendia pequenas fibras, ficando aderidas aos coletores. Quando colocados novamente sobre a bancada, a água que respingava nas laterais realizava uma lavagem carregando as fibras para dentro do reservatório, e as fibras que estavam no interior dos coletores eram levadas pela água que era despejada após a sua pesagem.

Não há relatos na literatura sobre os cuidados a serem tomados durante o procedimento de ensaio. Por vezes, medidas práticas adotadas para minimização de erros de leitura ou até mesmo para facilitar o procedimento, podem apresentar sérias consequências e interferir nos resultados finais. Devido aos pequenos tamanhos dos labirintos dos emissores e do material encontrado, a identificação desses problemas em um procedimento de ensaio torna-se muito complexa, principalmente quando não há disponibilidade de equipamentos que possibilitem uma melhor visualização sobre a situação dos labirintos. Devido a magnitude do 
problema, é possível que qualquer material indesejado que entre no sistema, seja por materiais que possam cair sobre a bancada ou mesmo por materiais que estejam sendo utilizados no procedimento, apresentam potencial de obstrução devido as pequenas dimensões dos labirintos de gotejadores.

Diante dos resultados obtidos, é possível afirmar que a presença desses materiais indesejados comprometeu os resultados desse ensaio, uma vez que o comportamento dos emissores foi influenciado por fatores não controlados. A influência da presença das fibras na água é mais evidente quando os resultados são comparados com os resultados obtidos pelos ensaios posteriores, aprestados no decorrer desse trabalho.

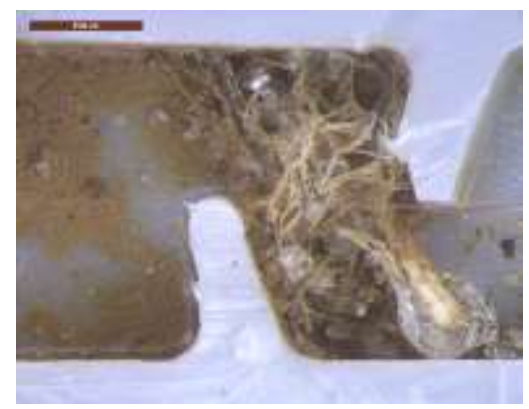

a)

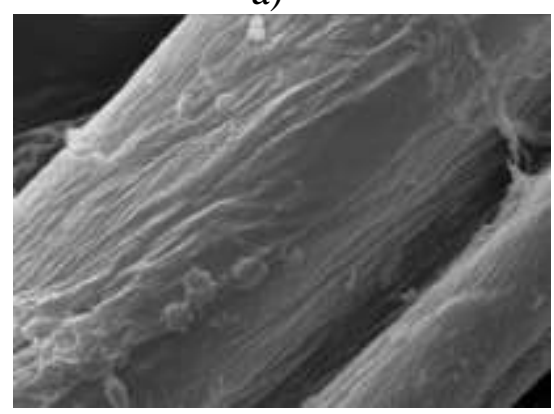

d)

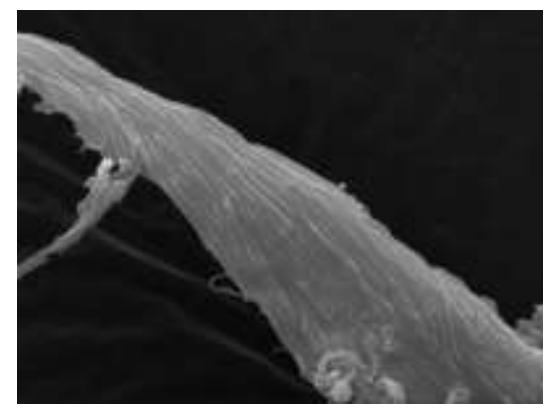

b)

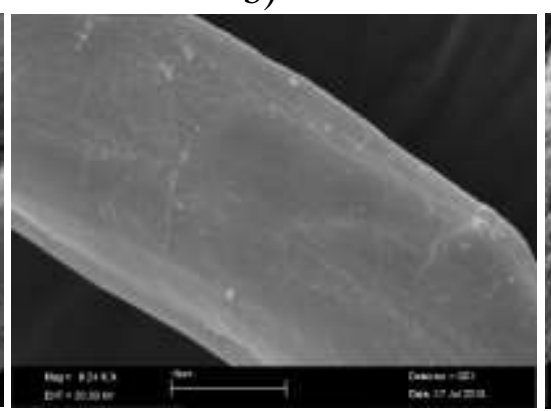

e)



c)

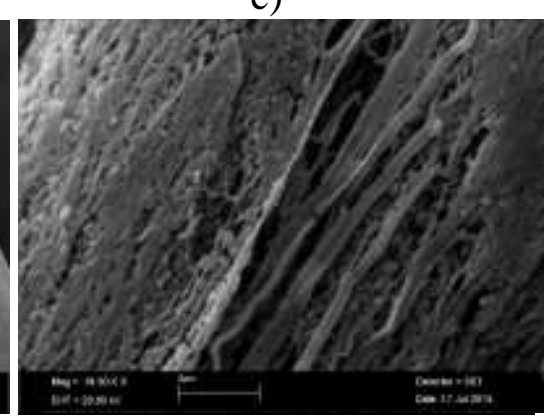

f)

Figura 12 - Material no interior do gotejador (a); imagem microscópica do material encontrado no gotejador (b e c); imagem do microscópio do pano utilizado para secagem dos coletores (d); imagem do microscópio do barbante (e); e imagem do microscópio da veda rosca (f)

\subsection{Ensaios definitivos}

Após os problemas com as fibras identificados durante os ensaios preliminares, foram tomadas algumas medidas preventivas para evitar problemas. Conforme será discutido a frente, essas medidas foram efetivas e evitaram a recorrência dos problemas identificados anteriormente. Não foi mais realizada a secagem dos coletores e também não foram mais utilizados barbantes de algodão nos emissores para condução da água até os coletores. Esses barbantes foram substituídos por barbantes de nylon, por não apresentar risco de desprendimento de fibras. Para esta segunda execução também foram instaladas cortinas plásticas na bancada e efetuou-se a cobertura do reservatório com uma tampa; as amostras de 
solo utilizadas nos ensaios foram submetidas a procedimentos de destruição de matéria orgânica conforme norma ISO 11277 (2009); e, efetuou-se cloração da água no início dos ensaios, sendo cuidados recomendados pela equipe LERMI/IRSTEA e que já foram descritos anteriormente.

Os dados de $\mathrm{pH}$ e temperatura da água para as três repetições em todos os dias de ensaio podem ser visualizados nas Figuras 13a e 13b. Pode-se observar que houve variações do $\mathrm{pH}$ ao longo dos ensaios nas três repetições variando em uma faixa entre 7 a 8,5. Para a temperatura da água também foram observadas pequenas variações ao longo dos dias, sendo observados maiores valores na última repetição, provavelmente devido ao aumento da temperatura ambiente que ocorreu na época do último ensaio.
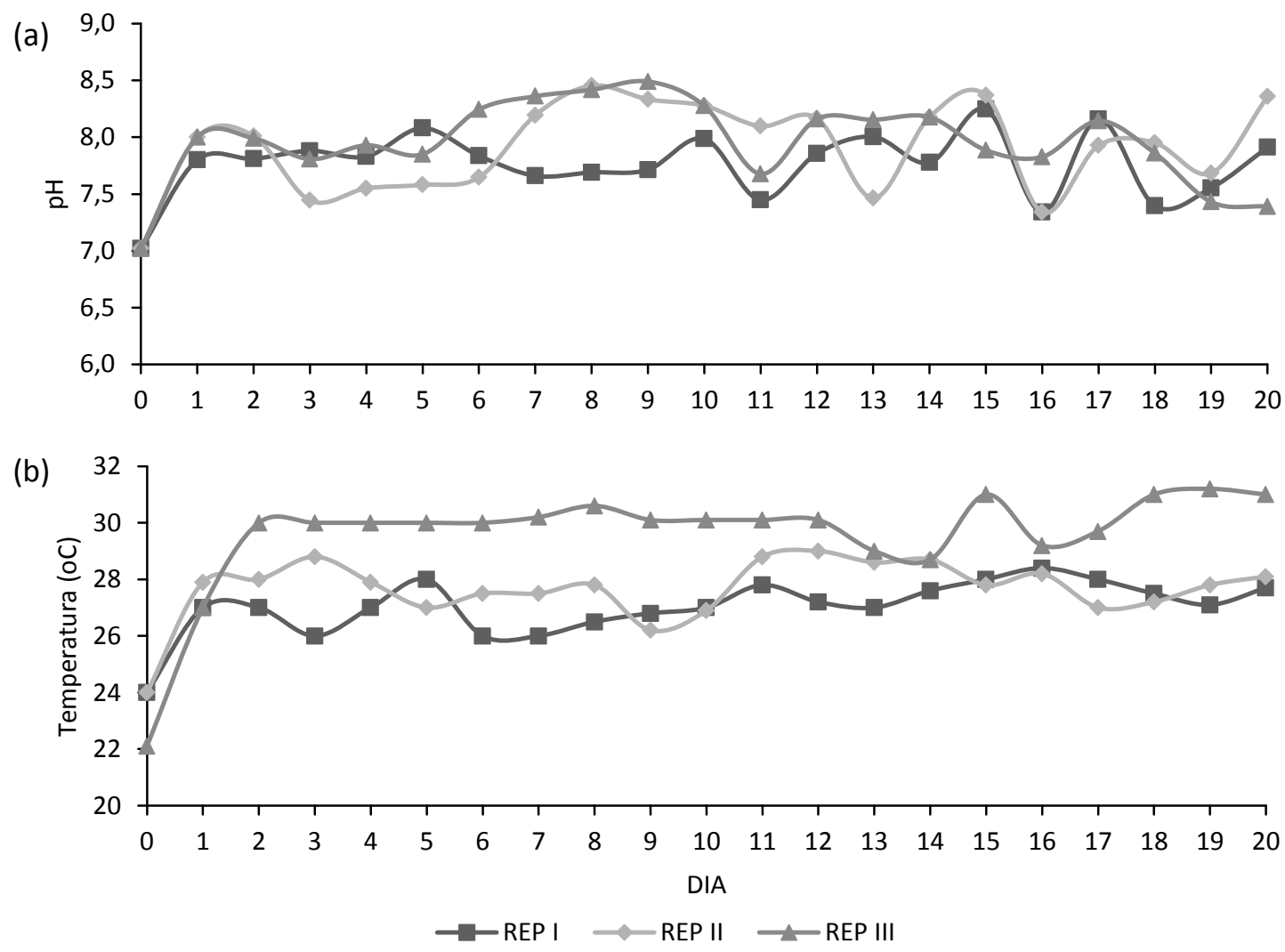

Figura 13 - pH (a) e temperatura da água (b) para cada repetição em cada dia de ensaio

Os gráficos apresentados na Figura 14 resumem os resultados de 3 repetições avaliando 4 modelos de tubogotejadores. Em cada gráfico, o eixo $\mathrm{X}$ corresponde ao dia do ensaio, no qual dados foram coletados, sendo que cada ensaio apresenta duração de 20 dias. $\mathrm{O}$ eixo Y a esquerda indica o grau de obstrução calculado (eq. 4) considerando a vazão de 26 gotejadores de cada modelo avaliado, sendo que esses dados são representados pela série constituída por círculos interligados por linha. $\mathrm{O}$ eixo $\mathrm{Y}$ a direita indica o número de 
gotejadores de cada modelo cujo grau de obstrução ultrapassou o limite de $25 \%$, sendo esses valores representados por colunas.

Em uma de cada três repetições dos modelos de gotejador Drip-Tech com vazões de $1,2 \mathrm{~L} \mathrm{~h}^{-1}$ e $1,6 \mathrm{~L} \mathrm{~h}^{-1}$, o grau de obstrução não atingiu exatamente $25 \%$, mas esse valor foi muito próximo do limite e permite assumir que a obstrução dos lotes de emissores foi caracterizada na quarta fase do ensaio. De modo subjetivo, tais modelos poderiam ser considerados moderadamente resistentes a obstrução causada por partículas sólidas. O sistema de filtragem que poderia ser indicado para uso em conjunto com tais emissores deveria assegurar a retenção de partículas com granulometria superior a $212 \mu \mathrm{m}$. Um filtro com malha correspondente a 80 mesh (abertura de $177 \mu \mathrm{m}$ ) seria adequado para uso com esses modelos de emissores.

$\mathrm{O}$ modelo Taldrip 1,7 $\mathrm{L} \mathrm{h}^{-1}$ não obstruiu em nenhuma das fases do ensaio, sendo considerado um emissor resistente a obstrução causada por partículas físicas. Uma vez que esse modelo de gotejador não obstruiu com partículas com diâmetro de até $500 \mu \mathrm{m}$, poderia ser afirmado que um filtro com malha correspondente a 35 mesh (abertura de $500 \mu \mathrm{m}$ ) seria suficiente.

Em duas das três repetições avaliando o modelo Taldrip $0,6 \mathrm{~L} \mathrm{~h}^{-1}$, a obstrução do lote de emissores foi caracterizada logo no primeiro dia de ensaios. Mesmo na terceira repetição do ensaio, observou-se que esse modelo de emissor obstruiu ainda na primeira fase do ensaio. Deve-se lembrar que a primeira fase é caracterizada por partículas finas, cujo diâmetro varia entre 0 e $75 \mu \mathrm{m}$. Respeitando-se as condições de ensaio adotadas nessa pesquisa, considera-se que esse modelo de emissor foi muito sensível a obstrução por partículas sólidas, não havendo sequer uma recomendação de filtragem para viabilizar seu uso em sistemas de irrigação por gotejamento.

As malhas de filtragem indicadas para cada modelo de emissor devem ser interpretadas apenas como um exercício demonstrativo da utilidade das informações obtidas nesses ensaios. Tais informações não devem ser adotadas para uso prático, uma vez que o procedimento de ensaios utilizado ainda está em fase desenvolvimento, podendo não refletir a condições de campo nas quais os emissores operam.

Pelo comportamento das curvas de grau de obstrução observa-se que não houve tendências entre repetições, ou seja, uma repetição que apresentou maior grau de obstrução em um modelo de emissor não foi necessariamente a mesma repetição que apresentou maior grau de obstrução nos outros modelos. Essas diferenças obtidas entre os emissores indicam 
que os fatores não controlados que exercem influência sobre a obstrução dos emissores afetaram cada modelo com intensidades diferentes. 



Figura 14 - Grau de obstrução e número de emissores obstruídos nas três repetições para os quatro modelos estudados 
Analisando-se resultados do emissor Taldrip 1,7 $\mathrm{L} \mathrm{h}^{-1}$ (Figura 14 e Figura 15), pode-se supor que, entre repetições, houve baixa variabilidade dos resultados obtidos. Ao longo dos ensaios verifica-se que as diferenças entre valores máximos e mínimos de grau de obstrução entre repetições foram de até $8,9 \%$. Devido à falta de parâmetros que indiquem a variação admissível que pode ser observado entre repetições realizadas para ensaios de obstrução de emissores, é difícil afirmar se a variabilidade dos resultados obtidos entre as repetições estão em um nível aceitável ou não. Arbitrariamente, supõe-se que os resultados de grau de obstrução obtidos para o modelo Taldrip $1,7 \mathrm{~L} \mathrm{~h}^{-1}$ apresentaram repetitividade adequada. Além disso, acredita-se que não houve influência significativa de fatores não controlados nos ensaios desse modelo de emissor, pois os resultados entre repetições foram similares. Tal conclusão seria desejável pois indicaria que a metodologia de ensaios apresenta adequada repetitividade nos resultados de medição.

Por outro lado, a variabilidade entre resultados de medição para sucessivas repetições foi excessiva analisando-se os outros modelos de emissores (Figura 14 e Figura 15). Analisando-se as diferenças entre valores máximos e mínimos de grau de obstrução entre repetições para os outros três modelos de gotejadores, supõe-se que a repetitividade dos resultados seja insatisfatória (Figura 15). As diferenças entre valores máximos e mínimos de grau de obstrução entre repetições foram de até 16\%, 31,7\% e 67,6\% para os modelos DripTech 1,2 L h ${ }^{-1}$, Drip-Tech $1,6 \mathrm{~L} \mathrm{~h}^{-1}$ e Taldrip $0,6 \mathrm{~L} \mathrm{~h}^{-1}$, respectivamente.

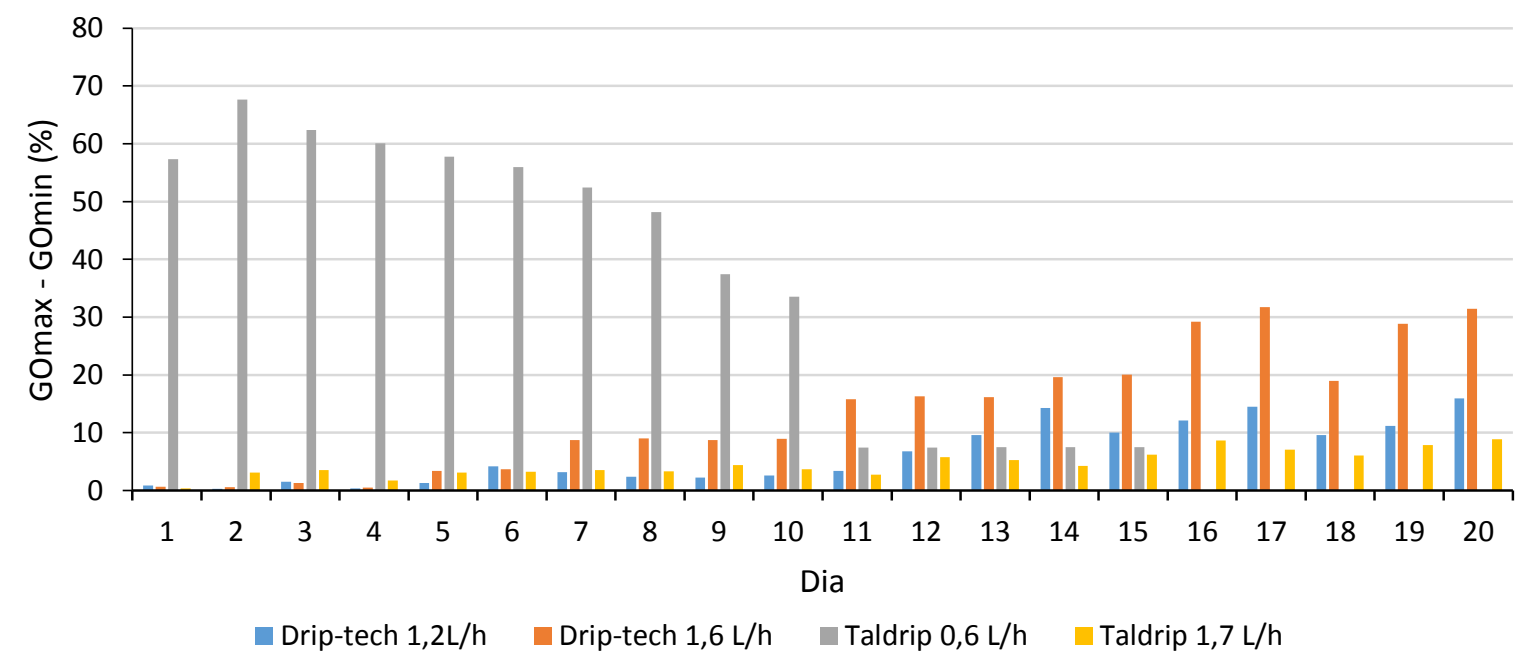

Figura 15 - Diferenças entre grau de obstrução máximo e mínimo entre repetições para os quatro modelos de emissores estudados 
É provável que fatores não controlados apresentaram significativa influência nos processos de obstrução. Tal fato explicaria a variabilidade observada nos resultados obtidos em sucessivas repetições.

O procedimento de ensaios avaliado estabelece a granulometria e a concentração de partículas a ser adicionada ao reservatório no início de cada fase do ensaio. Não é exigido que sejam realizadas rotinas de monitoramento e/ou correção da concentração de partículas no reservatório. Observações durante os ensaios indicam claramente que, se não forem tomadas as devidas precauções, é possível que impurezas externas atinjam o reservatório aumentando a concentração de partículas, ou ainda, que haja uma redução da concentração de partículas no reservatório devido a sedimentação das mesmas em dados locais da bancada de ensaios ou do próprio reservatório. Variações na concentração de partículas afetam diretamente o potencial de obstrução da água utilizada nos ensaios. Todavia, o monitoramento direto ou indireto da concentração de partículas dispersas na água requer o uso de um método bastante exato, visto que as concentrações de partículas empregadas são baixas (entre 125 e 500 ppm). Como exemplo, na primeira fase do ensaio, adiciona-se apenas 31,25 g de partículas em $250 \mathrm{~L}$ de água (concentração de 125 ppm). A determinação exata de tais concentrações constitui um desafio, de modo que a identificação de metodologias ou instrumentos de medição apropriados para monitoramento da concentração de partículas suspensas na água, assim como a adoção de rotinas de correção dessas concentrações constituem um problema a ser tratado em pesquisas futuras.

A possibilidade de precipitação de íons durante os ensaios é outro fator que pode ter influenciado na variabilidade de resultados observados entre as repetições. Segundo Nakayama e Bucks (1991) valores de $\mathrm{pH}$ entre 7 e 8 e acima de 8 apresentam potencial de obstrução moderado e severo, respectivamente. Embora, nesse estudo, não tenha sido efetuado controle de $\mathrm{pH}$ da água, essa variável foi monitorada diariamente durante os ensaios, permanecendo entre valores de 7 a 8,5 (Figura 13a) apresentando valores diferentes entre as três repetições. Todos os ensaios foram conduzidos utilizando água destilada, que apresenta reduzida concentração de elementos químicos e outras impurezas. Entretanto, deve-se lembrar que partículas de solo eram adicionadas à agua e portanto elementos químicos com potencial de precipitação poderiam estar presentes na água utilizada nos ensaios.

Em um estudo realizado por Liu e Huang (2009), avaliando o comportamento de emissores operando com efluente de esgoto tratado e água potável, disponível na rede de abastecimento na China, foram observados valores de $\mathrm{pH}$ próximo aos obtidos neste trabalho. Os valores de pH para o efluente e a água potável foram de 8,6 e 7,49, respectivamente, 
enquadrando-se dentro da faixa de risco proposta por Nakayama e Bucks (1991). Segundo os autores, a precipitação de íons, causada pelo elevado $\mathrm{pH}$, foi a principal responsável pela obstrução dos emissores estudados.

A atividade biológica na água e o respectivo risco de desenvolvimento de biofilme é outro fator não controlado que pode ter influenciado na baixa repetitividade dos resultados observados entre repetições. A presença de materiais gelatinosos, como biofilme, no interior do emissor agem como adesivos que facilitam o acumulo de partículas, proporcionando a obstrução gradual dos emissores (ADIN; SACKS, 1991). Foi realizado procedimento de desinfecção da bancada e dos tubogotejadores somente no início dos ensaios, quando os tubogotejadores eram substituídos. Conforme já mencionado, a cloração foi o método empregado para essa finalidade. Porém, o cloro livre é facilmente degradado, ocorrendo seu desaparecimento pouco tempo depois de ser aplicado. Uma vez que não foi realizada a reposição de cloro ao longo dos ensaios, há a possibilidade de que tenha ocorrido formação de biofilme devido à falta de um controle contínuo da atividade biológica na água utilizada.

É difícil atribuir a variabilidade dos resultados obtidos entre as repetições à uma causa específica, uma vez que a obstrução é influenciada por diversos fatores e que esses fatores interagem entre si. É necessário a realização de estudos que possam identificar as prováveis causas dessa variabilidade e minimizá-las o tanto quanto possível, seja pelo processo de cloração, para evitar o desenvolvimento de biofilme, ou pelo controle de $\mathrm{pH}$ para evitar a precipitação de íons. Mesmo que todos os fatores sejam controlados, ainda é possível que haja variações entre as repetições, podendo ser inerentes a variações construtivas entre os emissores devido a imperfeições no processo de fabricação, que também podem explicar a obstrução de emissores mesmo em fases menos sensíveis. A Figura 16 mostra o interior de um emissor do modelo Drip-Tech 1,2 $\mathrm{L} \mathrm{h}^{-1}$ que apresentou uma "rebarba" no caminho de passagem de água, devido à falhas no processo de fabricação. Espera-se que um problema dessa natureza seja pontual, pois seria grave se tal defeito fosse comum nos processos de fabricação desse modelo de emissores. 




Figura 16 - Detalhe do emissor Drip-Tech 1,2 $\mathrm{L} \mathrm{h}^{-1}$ que apresentou uma "rebarba" devido a falhas no processo de fabricação

\subsection{Avaliação da obstrução dos emissores em função das dimensões}

Com base na Figura 14, observa-se que a sensibilidade à obstrução dos modelos DripTech 1,6 e 1,2 $\mathrm{L} \mathrm{h}^{-1}$ foram semelhantes. Com exceção da primeira repetição para o modelo de vazão de $1,6 \mathrm{~L} \mathrm{~h}^{-1}$, que apresentou maior nível de redução de vazão, os valores de grau de obstrução apresentaram comportamento similares entre os dois modelos estudados. Para os dois modelos foram obtidos níveis de obstrução maiores na última fase de ensaio podendo-se dizer que ambos os emissores são sensíveis à partículas com granulometria superior a 212 $\mu \mathrm{m}$.

Apesar de terem vazões diferentes, os dois modelos Drip-Tech apresentam características arquitetônicas similares (Figura 1), assim como suas dimensões, variando apenas a profundidade do canal. Pode-se supor que a diferença na profundidade do canal não influenciou no desempenho dos emissores. Conforme observado por Li et al. (2006), que estudando a geometria de labirintos de emissores, observaram que o efeito da profundidade do canal na taxa de passagem de partículas não foi significativo, sendo a obstrução é mais afetada pelo espaçamento, ângulo e altura dos dentes. Desta forma, nem sempre emissores de menor vazão apresentam maior sensibilidade à obstrução que emissores de maior vazão.

Analisando a Figura 14, pode-se observar que o modelo Taldrip $0,6 \mathrm{~L} \mathrm{~h}^{-1}$ foi o mais sensível à obstrução. O modelo apresentou grande sensibilidade logo na primeira fase, em que 
foi utilizado partículas com granulometria inferior a $75 \mu \mathrm{m}$ e concentração de $125 \mathrm{ppm}$. A obstrução precoce desses emissores pode ser atribuída às pequenas dimensões do labirinto (Figura 1) quando comparada aos outros modelos. Em nenhuma das repetições foi observado emissores que chegaram ao fim do ensaio em funcionamento.

O modelo Taldrip $1,7 \mathrm{~L} \mathrm{~h}^{-1}$ foi o mais resistente à obstrução não atingindo o critério de $25 \%$ de obstrução em nenhuma das fases. No entanto, foi observado uma pequena redução da vazão média dos emissores nas três repetições, principalmente na última fase acompanhado da obstrução completa de alguns emissores. Assim, pode-se afirmar que partículas com dimensões entre 212 e $500 \mu \mathrm{m}$ pode afetar o desempenho de alguns emissores em campo. A maior resistência desse modelo possivelmente se deve às grandes dimensões de seu canal de escoamento, que não permite o acúmulo de partículas no labirinto.

É difícil afirmar se a obstrução é causada pelo aumento da concentração ou pela granulometria do material. Pela forma que o ensaio foi conduzido, presume-se que se os emissores não atingem o critério de obstrução em uma determinada fase, esses emissores são resistentes à obstrução para aquela faixa granulométrica. No entanto, não se tem garantias de que se houver aumento da concentração da faixa granulométrica correspondente as primeiras fases de ensaio, em que os emissores não foram obstruídos, os emissores apresentarão o mesmo comportamento. Assim como nesta metodologia de ensaio, Adin e Sacks (1991) afirmam que a severidade da obstrução depende mais do tamanho do que da quantidade de partículas na água de irrigação. Os autores observaram que quando o sistema foi operado com água contendo partículas de diâmetro entre 100 e $300 \mu \mathrm{m}$ houve redução da vazão dos emissores. No entanto, quando o sistema foi operado apenas com presença de partículas em suspensão com diâmetro inferior a $100 \mu \mathrm{m}$, mesmo em concentrações mais elevadas, não foi observado variações na vazão dos emissores avaliados.

Por outro lado, Niu, Liu e Chen, (2013) estudando obstrução de emissores utilizando partículas com diâmetro inferior à $100 \mu \mathrm{m}$, observaram que além da granulometria das partículas, a concentração também exerceu influência significativa na redução da vazão dos emissores, sendo que a vazão média reduziu com o aumento da concentração de sedimentos. Para concentrações na faixa de 0,5 a 1,25 $\mathrm{g} \mathrm{L}^{-1}$, ocorreram mudanças moderadas na vazão dos emissores, porém, não em intensidades críticas. Quando a concentração de partículas, de mesma granulometria, foi igual ou superior $1,25 \mathrm{~g} \mathrm{~L}^{-1}$, a situação da obstrução tornou-se mais severa, sendo observado maior redução na vazão dos emissores, indicando assim que foram obstruídos. 
Dessa forma, para que uma metodologia seja mais adequada, torna-se necessário considerar todos os fatores importantes relacionados à obstrução causada por partículas sólidas. Contudo, diante da dificuldade e do tempo necessário para avaliação da sensibilidade de emissores à obstrução utilizando procedimentos de laboratórios, deve-se buscar uma metodologia simplificada, que seja capaz de refletir as condições de campo e produzir resultados com adequada repetitividade.

Após o término dos ensaios, emissores foram abertos para analisar a quantidade e o local do acúmulo de material no labirinto. Foi observado que o acúmulo de partículas pode ocorrer tanto na entrada quanto ao longo do labirinto (Figura 18). Niu, Liu e Chen (2013) também observaram obstrução com essas características. Os autores dividiram o acúmulo de partículas em três locais: entrada, ao longo do labirinto, e saída. Segundo os autores, na entrada a água sofre redução repentina de velocidade de fluxo, proporcionando a deposição de partículas. Já no interior do labirinto, os autores explicam que existem zonas de circulação que apresentam fluxo com baixa velocidade e pressão, e quando as partículas entram nessas áreas são facilmente depositadas e acumuladas no local. Foi observado que o acúmulo na saída do labirinto não é tão comum, uma vez que essa região é ligada a parte externa do tubo, local onde a diferença de pressão é elevada facilitando a saída das partículas.

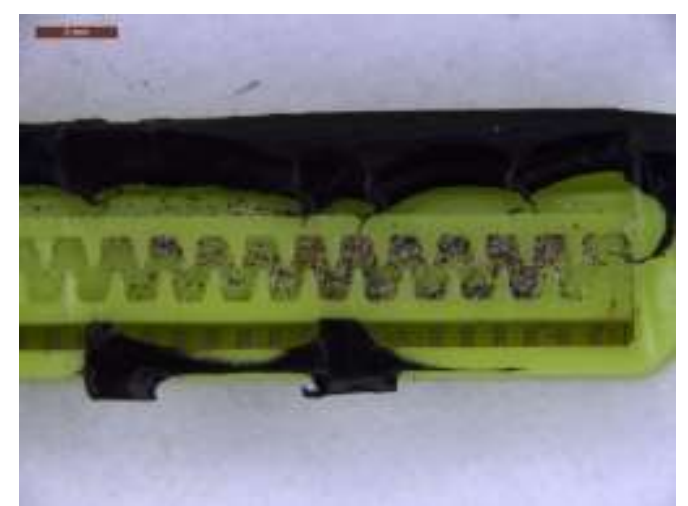

a)



c)



b)

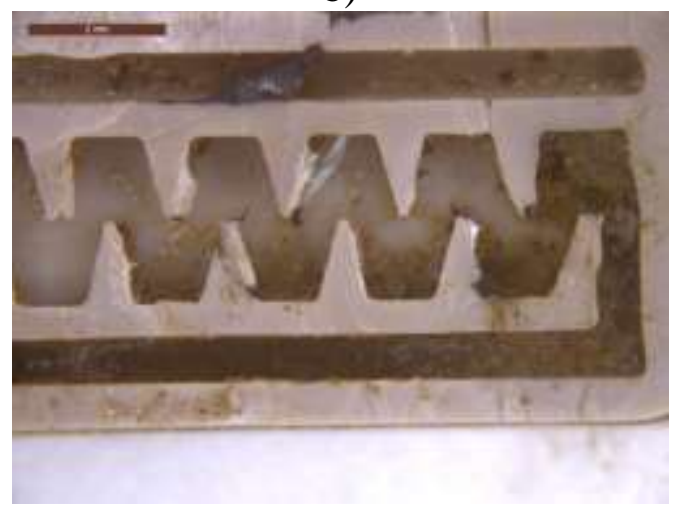

d)

Figura 17 - Obstrução ocorrida no meio do labirinto para o emissor Taldrip $0,6 \mathrm{~L} \mathrm{~h}^{-1}$ (a); obstrução na entrada do labirinto no modelo Taldrip $0,6 \mathrm{~L} \mathrm{~h}^{-1}$ (b); Drip-Tech 1,6 $\mathrm{L} \mathrm{h}^{-1}$ (c); e Taldrip 1,7 $\mathrm{L} \mathrm{h}^{-1}$ (d) 
Foi observado no presente trabalho que a obstrução pode ocorrer de duas formas: 1) pelo acúmulo de partículas de areia, especialmente, nas primeiras curvas do labirinto; ou, 2) pela agregação de partículas de pequeno diâmetro (silte e argila) (Figura 19) em qualquer posição do labirinto. A obstrução devido a agregação de partículas foi observada somente no emissor Taldrip $0,6 \mathrm{~L} \mathrm{~h}^{-1}$, enquanto que nos outros três modelos foi identificado obstrução apenas pelo acúmulo de partículas de areia. Possivelmente, justifica-se a ocorrência da primeira forma de obstrução se deve às características geométricas dos emissores que provavelmente não possibilitam o acúmulo de agregados de argila, ou pelas características de fluxo que não favorecem a formação de agregados com dimensões suficientes para obstruir os emissores.

A fim de quantificar a frequência com que ocorreu obstrução por agregação de partículas pequenas, foram abertos todos os emissores obstruídos na repetição II e III. Na repetição II foi observado que o fenômeno ocorreu em 32,35\% dos emissores, enquanto que na repetição III foi de $29 \%$. Resultados semelhantes foram observados por Niu, Liu e Chen (2013) que trabalhando com obstrução de emissores com partículas com diâmetro inferior a $0,1 \mathrm{~mm}$ observaram que as forças na superfície das partículas eram relativamente elevadas e ao se movimentar com a água essas partículas interagiam entre si, se aderindo e formando flocos que aumentaram gradualmente, cimentando e aderindo à parede do canal bloqueando a passagem de fluxo.

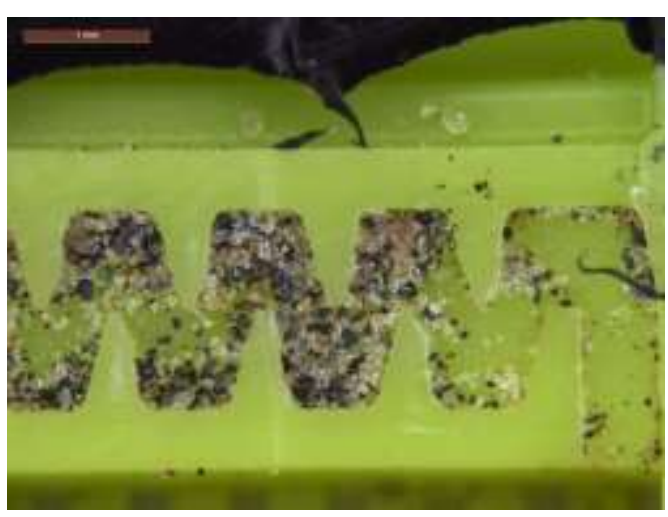

a)



b)

Figura 18 - Obstrução ocorrida pelo acúmulo de partículas de areia (a) e obstrução ocorrida pela formação de agregados de argila (b) 


\section{CONCLUSÕES}

O procedimento de ensaios permitiu a identificação da fase na qual ocorre a obstrução de quatro modelos de gotejador.

É provável que o procedimento de ensaio avaliado não considera fatores que apresentaram influência significativa nos processos de obstrução. A existência de fatores não controlados que são relevantes nesses processos explicaria a variabilidade observada nos resultados obtidos em sucessivas repetições.

É difícil atribuir a variabilidade dos resultados obtidos entre as repetições à uma causa específica, uma vez que a obstrução é influenciada por diversos fatores e que esses fatores interagem entre si. É necessária a realização de estudos que possam identificar as prováveis causas dessa variabilidade e minimizá-las o tanto quanto possível. Supõe-se que a repetitividade dos resultados de ensaio podem ser melhoradas adotando-se rotinas diárias de monitoramento e correção da concentração de partículas no reservatório, $\mathrm{pH}$ da água e cloro livre.

Considera-se que o procedimento de ensaios deve ser aprimorado através da identificação e controle de outros fatores relevantes para o processo de obstrução, a fim de que a repetitividade dos resultados seja melhor e o procedimento de ensaios torne-se mais apropriado. 


\section{REFERÊNCIAS}

ADIN, A.; SACKS, M. Dripper-clogging factors in wastewater irrigation. Journal of the Irrigation and Drainage Engineering, New York, v. 117, n. 6, p. 813-826, 1991.

ASSOCIAÇÃO BRASILEIRA DE NORMAS TÉCNICAS. ABNT NBR ISO 9261: equipamentos de irrigação agrícola - emissores e tubos emissores - especificação e métodos de ensaio. Rio de Janeiro, 2006. 17 p.

BERNARDO, S.; SOARES, A.A.; MANTOVANI, E.C. Manual de irrigação. 8. ed. Viçosa: UFV, 2006. $625 \mathrm{p}$.

BORSSOI, A.L.; VILAS BOAS, M.A.; REISDÖRFER, M.; HERNÁNDEZ, R.H.; FOLLADOR, F.A.C. Water application uniformity and fertigation in a dripping irrigation set. Engenharia Agrícola, Jaboticabal, v. 32, n. 4, p. 718-726, ago. 2012.

BOUNOUA, S. Etude du colmatage des systemes s'irrigation localisee. 2010. 116 p. Thèse (Docteur d'aix marseille universite I Espécialité Mécanique et physique des fluides) Universite de Provence Aix-Marseille I, Aix-en-Provence, 2010.

BRALTS, V.F.; WU, I.P.; GITLIN, H.M. Drip irrigation uniformity considering emitter plugging. Transactions of the ASABE, St. Joseph, v. 24, n. 5, p. 1234-1240, 1981.

BUCKS, D.A.; NAKAYAMA, F.S.; GILBERT, R.G. Trickle irrigation water quality and preventive maintenance. Agricultural Water Management, Amsterdam, v. 2, p. 149-162, 1979.

CAMARGO, A.P.; MOLLE, B.; TOMAS, S.; FRIZZONE, J.A. Assessment of clogging effects on lateral hydraulics: proposing a monitoring e detection protocol. Irrigation Science, Amsterdam, v. 32, n. 3, p.181-191, 2013.

CAMARGO, O.A.; MONIZ, A.C.; JORGE, J.A.; VALADARES, J.M.A.S. Métodos de análise química, mineralógica e física de solos do Instituto Agronômico de Campinas. Campinas: Instituto Agronômico, 2009. 77 p. (Boletim técnico, 106).

EUROPEAN COOPERATION FOR ACREDITATION OF LABORATORIES. EAL-P11: Validation of test methods: general principles and concepts. Paris, 1997. 13 p.

FARIA, L.A. Proposta de norma técnica de ensaio para tubogotejadores de irrigação: resistência ao entupimento por particulados sólidos em suspensão. 2013. 129 p. Tese (Doutorado em Irrigação e Drenagem) - Escola Superior de Agricultura "Luiz de Queiroz", Universidade de São Paulo, Piracicaba, 2013.

GIRÃO, E.G.; ANDRADE, E.M.; ROSA, M.F.; ARAÚJO, L.F.P.; MEIRELES, A.C.M. Seleção dos indicadores da qualidade de água no Rio Jaibaras pelo emprego da análise da componente principal. Revista Ciência Agronômica, Fortaleza, v. 38, n. 1, p. 17-24, 2007.

HILLEL, D. Introduction to environmental soil physics. New York: Academic Press, 2003. $494 \mathrm{p}$. 
INSTITUTO NACIONAL DE METROLOGIA, QUALIDADE E TECNOLOGIA. DOQCGCRE-008: orientação sobre validação de métodos analíticos. Rio de Janeiro, 2010. 20 p.

INTERNATIONAL ORGANIZATION FOR STANDARDIZATION. ISO 8486-1: bouded abrasives - determination and designation of grain size distribution - part 1: macrogrits $\mathrm{F} 4$ to F220. Geneva, 1996. 5 p.

. ISO 11277: soil quality - determination of particle size distribution in mineral soil material - method by sieving and sedimentation. Geneva, 2009. 34 p.

LAMM, F.R.; CAMP, C.R. Subsurface drip irrigation. In: : LAMM, F.R.; AYARS, J.E.; NAKAYAMA, F.S. Microirrigation for crop production. Amsterdm: Elsevier, 2007. chap. 13, p. 473-551.

LI, G.Y.; WANG, J.D.; ALAM, M.; ZHAO, Y.F. Influence of geometrical parameters of labyrinth flow path of drip emitters on hydraulic and anti-clogging performance.

Transactions of the ASABE, St. Joseph, v. 49, n. 3, p. 637-643, 2006.

LI, Y.K.; LIU, Y.Z.; LI, G.B.; XU, T.W.; LIU, H.S.; REN, S.M.; YAN, D.Z.; YANG, P.L. Surface topographic characteristics of suspended particulates in reclaimed wastewater and effects on clogging in labyrinth drip irrigation emitters. Irrigation Science, New York, v. 30, n. 1, p. 43-56, 2012.

LIU, H.; HUANG, G. Laboratory experiment on drip emitter clogging with fresh water and treated sewage effluent. Agricultural Water Management, Amsterdam, v. 96, n. 5, p. 745756, 2009.

NAKAYAMA, F.S.; BUCKS, D.A. Emitter clogging effects on trickle irrigation uniformity. Transactions of the ASABE, St. Joseph, v. 24, n. 1, p. 77-80, 1981.

NAKAYAMA, F.S.; BUCKS, D.A. Water quality in drip/trickle irrigation: A review. Irrigation Science, Amsterdam, v. 12, n. 4, p.187-192, 1991.

NIU, W.; LIU, L.; CHEN, X. Influence of fine particle size and concentration on the clogging of labyrinth emitters. Irrigation Science, Amsterdam, v. 31, n. 4, p.445-455, 2013.

PINTO, M.F.; CAMARGO, A.P.; ALMEIDA, A.C.S.; ALVES, D.G.; BOTREL, T.A. Desenvolvimento de um sistema para o controle do $\mathrm{pH}$ da água para microirrigação. Revista Brasileira de Engenharia Agrícola e Ambiental, Campina Grande, v. 15, n. 2, p. 211-217, 2011.

PIZARRO, F. Riegos localizados de alta frequencia. 3. ed. Madrid: Mundi Prensa, 1996. $513 \mathrm{p}$.

POVOA, A.F.; HILLS, D.J. Sensitivity of micro irrigation system pressure to emitter plugging and lateral line perforations. Transactions of the ASABE, St. Joseph, v. 37, n. 3, p. 793-799, 1994.

PUIG-BÁRGUÉS, J.; LAMM, F.R. Effect of flushing velocity and flushing duration on sediment transport in microirrigation driplines. Transactions of the ASABE, St. Joseph, v. 56, n. 5, p. 1821-1828, 2013. 
PUIG-BARGUÉS, J.; LAMM, F.T.; TROOIEN, T.P.; CLARK, G.A. Effect of dripline flushing on subsurface drip irrigation systems. Transactions of the ASABE, St. Joseph, v. 53, n. 1, p. 147-155, 2010.

QINGSONG, W.; GANG, L.; JIE, L.; YUSHENG, S.; WENCHU, D.; SHUHUAI, H. Evaluations of emitter clogging in drip irrigation by two-phase flow simulations and laboratory experiments. Computers and Electronics in Agriculture, New York, v. 63, n. 2, p. 294-303, 2008.

RAVINA, I.; PAZ, E.; SOFER, Z.; MARCU, A.; SAGI, G. Control of emitter clogging in drip irrigation with reclaimed wastewater. Irrigation Science, Amsterdam, v. 13, p. 129-139, 1992.

TALOZI, S.A.; HILLS, D.J. Simulating emitter clogging in a microirrigation subunit. Transactions of the ASABE, St. Joseph, v. 44, n. 6, p. 1503-1509, 2001.

TAYLOR, H.D.; BASTOS, R.K.X.; PEARSON, H.W.; MARA, D.D. Drip irrigation with waste stabilization pond effluents: solving the problem of emitter fouling. Water Science Technology, London, v. 31, n. 12, p. 417-424, 1995.

VEKARIYA, P.B.; SUBBAIAH, R.; MASHRU, H.H. Hydraulics of microtube emitters: a dimensional analysis approach, Irrigation Science, Amsterdam, v. 29, n. 4, p. 341-350, 2011.

WEI, Q.; SHI, Y.; LU, G.; DONG, W.; HUANG, S. Rapid Evaluations of anticlogging performance of drip emitters by laboratorial short-cycle tests. Journal of Irrigation and Drainage Engineering, New York, v. 134, n. 3, p. 298-304, 2008.

WU, I.P. An assessment of hydraulic design of micro-irrigation systems. Agricultural Water Management, Amsterdam, v. 32, n. 3, p.275-284, 1997. 